\title{
Cross-shelf variability in the Iberian Peninsula Upwelling System: impact of a mesoscale filament.
}

\author{
Vincent Rossi',a, V. Garçon ${ }^{\mathrm{a}}$, J. Tassel ${ }^{\mathrm{b}}$, J. B. Romagnan ${ }^{\mathrm{c}}$, L. Stemmann ${ }^{\mathrm{c}}$, F. \\ Jourdin $^{\mathrm{b}}$, P. Morin ${ }^{\mathrm{d}}$, Y. Morel ${ }^{\mathrm{a}, \mathrm{e}}$ \\ ${ }^{a}$ Laboratoire d'Études en Géophysique et Océanographie Spatiales, CNRS, 18 avenue Edouard \\ Belin, 31401 Toulouse Cedex 9, France. \\ ${ }^{b}$ Service Hydrographique et Océanographique de la Marine (SHOM), 13 rue du Chatellier CS \\ 30316, 29603 Brest Cedex, France. \\ ${ }^{c}$ Observatoire Océanographique de Villefranche BP 2806234 Villefranche/Mer, France. \\ ${ }^{d}$ UMR 7144 CNRS / UPMC, Station Biologique de Roscoff, Place G. Teissier, 29682 Roscoff \\ Cedex, France. \\ ${ }^{e}$ SHOM, 42 avenue Gaspard Coriolis, 31057 Toulouse, France.
}

\begin{abstract}
Based on a multidisciplinary survey in the Iberian upwelling during late summer 2007, this paper analysed comparatively the cross-shore variability and offshore transport across the upwelling front and within a mesoscale filament.

Along the East-West (EW) sections, transient upwelling pulses bring regularly cold, fresh and nutrient-enriched waters to the surface, triggering intense biological responses. Offshore advection by wind-forced Ekman drift of the successive fronts, interrupted by relaxation periods, drive the variability of the planktonic communities. While the near-shore areas are dominated by relatively small phytoplankton controlled by mesozooplankton grazing, large cells of diatoms appear after a short decay. While the microphytoplankton dominates largely the shelf communities, the species composition varies along the offshore drift with the apparition of dinoflagel-
\end{abstract}

\footnotetext{
${ }^{*}$ Corresponding author (email: vincent.rossi.ocean@gmail.com; now at IFISC/CSIC, Palma de Mallorca, Spain.

Email address: vincent.rossi.ocean@gmail.com (Vincent Rossi)
} 
lates and the development of large zooplankton individuals. The oligotrophic ecosystem characterized by small organisms and low biomass ( $\sim 80 \mathrm{~km}$ offshore) contrasts strongly with the transitional area and the coastal upwelling.

The low density waters within the filament and the existence of a pair of opposite rotating eddies at its base and tip promote its generation and rapid seaward extension. The intensified offshore advection of coastal enriched waters considerably increases the area favouring a productive ecosystem (until $\sim 160 \mathrm{~km}$ off the coast). Cross-shelf variability of bio-physical variables is observed in the filament as along EW sections, although a subsequent homogenization within the mesoscale structure erases the sharp fronts. Off the shelf within the filament, the chlorophyll $a$ is distinctly organised as a shallow subsurface maximum dominated by nanophytoplankton. The relative physical isolation of a dynamical food-web in the filament is also promoting nutrient remineralisation under the structure.

Finally, we estimate that mesoscale filaments, although being less extended meridionally than the upwelling front itself ( $\sim 40 \%$ of the length of the front) are responsible of a greater offshore transport of chlorophyll ( $\sim 60 \%$ of total cross-shelf exchanges) over the Iberian system. Despite the favourable wind pulses advecting westward the successive upwelling fronts, self-propelled filaments provide permanent offshore transport, even under wind relaxation period, thus playing a major role in cross-shelf exchanges.

Key words: Iberian Peninsula Upwelling, Cross-shore variability, Upwelling front, Mesoscale Filament, Biogeochemistry, Planktonic community

Abbreviations 1

\footnotetext{
${ }^{1}$ Eastern Boundary Upwelling Systems = EBUS; Iberian Peninsula Upwelling System = IPUS; Western Iberian Buoyant Plume = WIBP; Portugal Current $=$ PC; Portugal Coastal Current
} 


\section{Introduction}

Coastal upwelling systems are characterized by high productivity of plankton and pelagic fishes. thus having a maior biological and socio-economical role (Pauly and Christensen, 1995). Their positive effect is not only restricted to the continental margins where they occur, but it is also exported toward the adjacent oceanic gyre. Indeed, coastal upwellings exchange water and biogeochemical properties with the offshore regions through the complex and highly dynamical Coastal Transition Zones, the core of manv multidisciplinarv studies in the last two decades (Brink and Cowles, 1991; Barton et al., 1998; Fréon et al., 2009). It has been shown that mesoscale processes such as filaments and eddies are ubiquituous features of these transitional areas, in relation with the complex coastal circulation and bathymetry. These structures promote an intense transport from the productive shelf region toward the oligotrophic gyre, thus fueling the open ocean with coastal biogeochemical materials, including organic matter. Although it is difficult to precisely quantify those cross-shelf processes, a review by Arístegui et al. (2009) suggests they have an important role in the metabolic balance of the whole North Atlantic gyre.

This study is based on the MOUTON07 field experiment (Rossi, 2010) that took place in the Iberian Peninsula Upwelling System (IPUS). Although disconnected by the Gibraltar Strait, the IPUS is often associated to one of the four main winddriven Eastern Boundary Upwelling Systems (EBUS), the Canary-Iberian upwelling (Arístegui et al., 2009). However, an important difference between the Canary and

$\overline{=}$ PCC $;$ Iberian Poleward Current $=$ IPC $; \mathrm{SCM}=$ Subsurface Chlorophyll Maximum; $\mathrm{PP}=$ Primary Production; AOU = Apparent Oxygen Utilization; ESD = Equivalent Spherical Diameter; ENACWsp-st $=$ Eastern North Atlantic Central Water of Subpolar/Subtropical origins. 

${ }_{47}$ (picoplankton) are found in the oceanic waters. production (Joint et al., 2002). (Peliz et al., 2005).

Iberian areas is their temporal variability: the Canary region sees quasi-constant trade winds which favour upwelling all year round, whereas the IPUS shows a strong seasonality mainly due to the annual cycle of the atmospheric system. A winter regime and a summer-fall regime are observed, with superimposed smaller scales variability. During winter / early spring, weak equatorward winds occur transiently and are associated with localized upwelling and moderate response from the wellmixed waters (Castro et al., 2000). During late spring / summer / autumn when the stratification of the coastal ocean increases, a sustained along-shore southward wind stress generates a strong upwelling (Fiuza et al., 1982) of cold nutrients enriched waters at the coast, associated with an increase up to $50 \%$ of the total primary

During the favourable upwelling season, the physical circulation is complex and is composed of large scale currents interacting with numerous and intense meso-scale features (Relvas et al., 2007). The Portugal Current (PC), a south-west surface drift offshore, is established and is usually associated with a coastal jet flowing equatorward (Peliz et al., 2002), the Portugal Coastal Current (PCC). In addition, a poleward slope counter-current, named the Iberian Poleward Current (IPC), is observed at many periods of the year but intensified in non-upwelling season, i.e. winter

A quasi-meridional upwelling front develops between the cold recently upwelled enriched waters at the coast and warmer oligotrophic offshore waters. This strong cross-shore temperature gradient, itself related to the ambient nutrient concentrations, is indeed strongly influencing the phytoplankton assemblages (Resende et al., 2007). Tilstone et al. (2003) and Lorenzo et al. (2005) also described the coastal upwelling communities as microplankton dominated, whereas mainly cyanobacteria 
Due to small scales instabilities (Relvas et al., 2007), mesoscale processes such as filaments and eddies are commonly observed along the upwelling front, i.e. occurring mainly from July to October (upwelling season). Large filaments were often closely related with capes and coast irregularities, but the repeated occurrence of a few large filaments at different locations corresponding with a straight coastline have also been noted. Different processes have been studied (Haynes et al.,, 1993; Roed and Shi, 1999; Batteen et al., 2007; Sanchez et al.) and among others, the capes effect, front and flow instabilities resulting in meander formation, and lately the creation of vorticity anomalies by upwelling current/topography interactions (Meunier et al., 2010) can be cited.

Other authors focused on the biological role of these filamental structures. AlvarezSalgado et al. (2001, 2007) showed they are responsible for important cross-shelf exchange of biological material while seeding the oligotrophic offshore waters with nutrients and organic materials. Filaments also constitute ecological niches by themselves, where changes in biological process rates (Alvarez-Salgado et al..)2001: Fileman and Burkill, 2001). phvtoplankton (Joint et al..2001) and zooplankton populations (Batten et al., 2001; Halvorsen et al., 2001) occur within the structure during its offshore drift. In addition, Borges and Frankignoulle (2001) claimed that upwelling filaments are partly controlling the partial pressure of $\mathrm{CO}_{2}$ in the area, thus playing a key role in the inorganic carbon cycle and the ocean acidity regulation. More recently, (Cravo et al., 2010) studied an upwelling filament off south west Iberia and found that it carried large amount of chlorophyll $a$ as well as nutrient offshore the coastal upwelling front. A review of the existing bibliography in the north Atlantic showed that although variable, large amounts of nutrients, gases and plankton are exported toward the open ocean through these structures (Arístegui et al., 2009; Cravo et al., 2010). 
Overall, although the seasonality of the Iberian upwelling is linked with synoptic atmospheric systems, the system is also highly variable at smaller scale. During the upwelling season, a sharp meridional front is developing between the productive coastal waters and the oligotrophic open ocean, regularly interrupted by numerous filaments and eddies. The mesoscale variability of this transitional area, its influence on biogeochemical properties and planktonic communities, and its associated crossshelf export are still not properly quantified.

Based on a multidisciplinary data set collected over the central and northern IPUS during upwelling-favourable conditions in August-September 2007, the crossshore variability is investigated under two different situations. We compare two zonal sections through the sharp upwelling front at $40^{\circ}$ and $41^{\circ} \mathrm{N}$ to a network of transects carried out within and across a filament.

After presenting the oceanographic context (sect. 3.1), we briefly described the shelf circulation in section 3.2. We then compare the physical structure of the successive upwelling fronts and of the filament extending offshore (sect. 3.3). It results in specific biogeochemical and biological cross-shore variability examined in sect. 3.4 and 3.5. Finally, we estimate the contribution of both structures to seaward fluxes of enriched coastal waters (sect. 3.6) $)$.

\section{Materials and methods.}

\subsection{The MOUTON 2007 survey: general information and sampling strategy.}

The MOUTON07 cruise was conducted along the western coast of the Iberian Peninsula (mainly Portuguese coast), onboard the Research Vessel R/V "PourquoiPas?". It aimed at studying the mesoscale variability both from a physical and 
biogeochemical point of view in the central and northern part of the IPUS during the upwelling-favourable season.

The survey was divided in two legs, from August $14^{\text {th }}$ to August $25^{\text {th }}$ and then

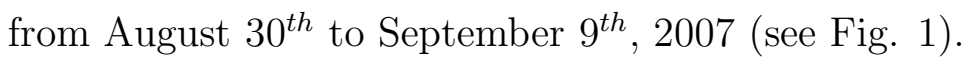

To study the cross-shore variability of the IPUS, two zonal sections across the quasi-meridional upwelling front and an intensive survey of a mesoscale filament were carried out thanks to real-time acquisition of satellite data onboard. Both East-West sections EW1 at $41^{\circ} \mathrm{N}$ and EW2 at $40^{\circ} \mathrm{N}$ started at around $10 \mathrm{~km}$ from the coast, crossed the upwelling front and ended at about $100 \mathrm{~km}$ offshore (see Fig. 1). The sampling was focused on a filament initiating at around $40.3^{\circ} \mathrm{N}$, elongating offshore almost zonally. A transect was first performed from the coast to $\sim 200 \mathrm{~km}$ offshore within the filament followed by several North-South transects across the structure (see Fig. 1 and Fig. 7h).

\subsection{Bio-physical sensors and water sampling.}

Physical observations were made using a Conductivity-Temperature-Depth (CTD) probe, a Lowered Acoustic Doppler Current Profiler (LADCP) functioning at $300 \mathrm{kHz}$, and two Vessel Mounted Acoustic Doppler Current Profilers (VMADCP), functioning at $38 \mathrm{kHz}$ and $150 \mathrm{kHz}$, respectively. Meteorological and underway data were simultaneously recorded from the sensors onboard the R/V. Sea surface winds derived from the QuikSCAT scatterometer (averaged over the surveyed area $39-43^{\circ} \mathrm{N}$ $/ 9-12^{\circ} \mathrm{W}$ ) are used when the onboard measurements were not available. Meanwhile, a set of biogeochemical as well as optical sensors were also mounted onto the CTD-rosette. In this paper, data from a fluorometer Chelsea Aqua 3 for chlorophyll $a$ and from an Oxygen sensor SBE43 lowered on the Rosette are presented.

More than a thousand CTD casts were carried out during the cruise (see Fig. 
1), composed of around 430 casts using a "physical CTD-Rosette" system lowered down to $2000 \mathrm{~m}$ at offshore locations and around 960 casts using a "biogeochemical CTD-Rosette-Niskin" system limited to the upper $200 \mathrm{~m}$ (due to the maximum operation depth of biogeochemical sensors). Among the "biogeochemical" stations, seawater samples were collected at around 150 stations using the biogeochemical rosette equipped with 12 ten litres Niskin bottles. In this paper, our analysis focus on the "biogeochemical" stations that compose the cross-shelf transects EW1, EW2 and the filament network, while the whole dataset provide an overview of the local oceanography down to $2000 \mathrm{~m}$.

At each station, the downcast profiles of temperature and fluorescence were used to visually determine up to five depths in the water column, sampled during the upcast: the surface $(1 \mathrm{~m})$, the upper thermocline, the deep chlorophyll maximum, the lower thermocline and an additional depth of interest.

Error estimates are around $5 \mathrm{~cm} / \mathrm{s}$ for all current sections presented here. Rough conditions occurred during the survey, especially during the leg 1, due to intense northerlies (see Fig. 2) and a large ground-swell $(\sim 3 \mathrm{~m})$ which affected the ship navigation offshore as compared to the relatively protected shelf areas. As a consequence, the open ocean currents data (for depths greater than $200 \mathrm{~m}$ ) are not analyzed in this paper.

The fluorometer (chlorophyll a probe) from the rosette was calibrated using chlorophyll $a$ concentration in $\mathrm{mg} / \mathrm{m}^{3}$ measured by HPLC (see Sec. 2.3.2). The values of total chlorophyll $a$ are obtained by multiplying the corresponding fluorescence by a factor of $3\left(R^{2}=0.75\right)$.

The oxygen probe was calibrated by independent sampling and Winkler titration following Labasque et al. (2004) (and references therein). The calibration samples were spread over the whole campaign to cover different biogeochemical provinces. 
Dissolved oxygen from the Winkler titrations and from the CTD probe are well correlated $\left(R^{2}=0.98\right)$ and the values measured by the CTD probe can be directly interpreted as oxygen concentrations (factor 1).

The Apparent Oxvgen Utilization (AOU) was computed according to Garcia and Gordon (1992) as the difference between the saturation value (depending on the corresponding temperature and salinity) and the measured dissolved oxygen.

\subsection{Biogeochemical and biological sampling.}

\subsubsection{Dissolved nutrients.}

The seawater samples collected onboard for nutrient analysis were stored at $-20^{\circ} \mathrm{C}$ for later analysis. The common nutrients concentrations - namely nitrate + nitrite, silicate and phosphate - were then determined in the labs (on land) by colorimetric methods using an Technicon Autoanalyser II, following the protocols and methods described in Aminot and Kerouel (2007).

\subsubsection{Phytoplanktonic pigments.}

The water samples for photoactive pigments analysis were collected at 2 or 3 depths and then were vacuum filtered through $25 \mathrm{~mm}$ diameter Whatman $\mathrm{GF} / \mathrm{F}$ fiber glass filters $(0.7 \mu \mathrm{m}$ particle retention size $)$. Filtered volumes varied between $3 \mathrm{l}$ in the offshore waters and less than 11 for some stations inside the coastal upwelling zone. The filters were immediately stored in liquid nitrogen until analysis on land. Among the total 219 samples, 16 were replicated and then analysed almost 
simultaneously by two laboratories to perform a cross-validation 2 .

Phytoplankton pigments composition was determined by High Performance Liquid Chromatography (HPLC) methods. The filters were extracted and then rapidly analysed (within $24 \mathrm{~h}$ ) by HPLC with a complete Agilent Technologies system. Following an adaptation of the method described by Heukelem and Thomas (2001), the concentrations (in $\mathrm{mg} / \mathrm{m}^{3}$ ) of 13 separate phytoplankton pigments (see Tab. 1) were calculated from the absorption spectra with an internal standard correction and external calibration. With a lower limit of detection for chlorophyll $a$ of $0.0001 \mathrm{mg} / \mathrm{m}^{3}$ and an injection precision of $0.4 \%$, the accuracy of this method has been largely proven (Ras et al., 2008). Additional pigments as phaeophorbide $a$ (phaeo-a), chlorophyllide $a$ (chloid-a) and divinyl chlorophyll $a$ (div-chlo-a) were measured only on a subset of the total samples.

While total chlorophyll $a$ is the universal proxy for phytoplankton organisms, accessory pigments are specific to phytoplankton groups (see Table 1), and their respective proportion to total chlorophyll $a$ is a proxy of the community composition. Seven pigments are used as biomarkers of several phytoplankton taxa: fucoxanthin (fuco), peridinin (peri), alloxanthin (allo), 19-butanoyloxyfucoxanthin (19-but), 19hexanovloxvfucoxanthin (19-hex). zeaxanthin (zea). total chlorophvll-b (chlo-b) (Ras et al., 2008). These taxa are then gathered into three size classes (micro- M, nano$\mathrm{N}$, and picophytoplankton $\mathrm{P}$ ), according to the average size of the cells ( $\mathrm{M}$ cell size $>20 \mu \mathrm{m}, \mathrm{N}$ size comprised between 2 and $20 \mu \mathrm{m}$, and $\mathrm{P}$ size $<2 \mu \mathrm{m}$ ). The fraction of each pigment-based size class with respect to the total phytoplankton biomass is calculated following Ras et al. (2008).

\footnotetext{
${ }^{2}$ On the common pigments that both labs measured, a very good agreement was found: e.g. $R^{2}$ of 0.91 for chlo-a, 0.96 for fuco and 0.94 for 19-hex
} 


\subsubsection{Zooplankton sampling.}

Zooplankton samples were collected during day and night at one CTD station out of two or three, with the highest possible frequency. A WP2 plankton net (mouth surface of $0.25 \mathrm{~m}^{2}$ ) mounted with $200 \mu \mathrm{m}$ mesh size was used, and towed vertically at around $1 \mathrm{~m} / \mathrm{s}$ over the water column from $5 \mathrm{~m}$ above the sea floor, or $70 \mathrm{~m}$ depth, up to the surface. The proper volume of water filtered was calculated using the effective depth of the tow as measured by a cable meter. The sample was then splitted into two fractions using a motoda box (Motoda, 1959) and a fraction was directly preserved in formaldehyde for later digitalisation, whereas the other half sample was fixed on a pre-weighted filter $(200 \mu \mathrm{m})$ and conserved at $-20^{\circ} \mathrm{C}$ in individual sterile cases.

Net collected zooplankton subsamples were digitized using the Zooscan imaging system (Gorsky et al., 2010) which is a high resolution waterproof scanner. Output raw images were processed enabling fast and reliable enumeration and measurements of objects (www.zooscan.com). A Motoda splitter (Motoda, 1959) was used for subsampling to obtain appropriate concentration of organisms. The digitization generates a raw image and a metadata form compiling various information for each sample. The outputs of the image process are a set of vignettes and an associated file compiling many parameters for each object including shape, length, size,...etc... When all samples were scanned and processed, an automatic sorting procedure was applied (for further details see (Gasparini, 2007; Gorsky et al., 2010)) to classify each vignette into coarse faunistical groups. In this work, living objects are separated from the non-living objects (marine snow, particulate organic matter, aggregates, bubbles...) to quantify exclusively zooplankton individuals. Their biomass was computed following an estimation of the biovolume based on size measurements from the Zooscan. For Copepods, major and minor axes of the best fitting ellipse 
were used whereas equivalent spherical diameter (ESD) was used for other organisms (Gorsky et al., 2010). Finally, two classes of size were defined by a limit volume of $1 \mathrm{~mm}^{3}$ that represent the small (Ciliates / small Copepods) and large individuals (large Copepods, Chaetognaths, meroplankton...) found in the area. Although the common criteria to differentiate micro- and meso- zooplankton is the body length, this biovolume approach is in accord with their distinct ecological function (Gorsky et al., 2010).

\section{Results and Discussion.}

\subsection{Meteorological conditions.}

Wind data from QuikSCAT scatterometer and from on-board measurement reveal that upwelling favourable wind conditions prevailed roughly during two months, from the end of July to the end of September 2007 (Fig. 2).

More specifically, strong equatorward winds from July $20^{\text {th }}$ to August $13^{\text {th }}$ were observed. These conditions led to a well developed upwelling of cold nutrient enriched waters $\left(\mathrm{SST} \sim 15^{\circ} \mathrm{C}\right.$ ) that spread within a $\sim 100 \mathrm{~km}$ width coastal band, with around 4-5 upwelling filaments extending up to $\sim 200 \mathrm{~km}$ offshore (see Fig. 3a1). Then a two days period of moderate-strong northward winds $(15 \mathrm{~m} / \mathrm{s})$ occurs from August $13^{\text {th }}$ to the $15^{\text {th }}$, mid-day (Fig. 2). After this short wind inversion, upwelling favourable wind conditions prevailed during the first leg of the cruise with intense equatorward wind (10 to $25 \mathrm{~m} / \mathrm{s})$ blowing during two weeks, from August $15^{\text {th }}$ to August $30^{\text {th }}$. These successive wind events led to the intensification of the coastal upwelling with temperature near the coast dropping to less than $14^{\circ} \mathrm{C}$ on the $23^{\text {rd }}$ of August (Fig. 3b1). At this date, the main front is located at about $\sim 150 \mathrm{~km}$ offshore (i.e. a westward displacement of $\sim 50 \mathrm{~km}$ in $\sim 15$ days), interrupted regularly by 4 main 
mesoscale filaments extending almost zonally up to 300 kmoffshore. From the $1^{\text {st }}$ of September, the winds are mainly equatorward but of lower intensity than the previous weeks $(\leq 13 \mathrm{~m} / \mathrm{s})$.

Based on our analysis of Fig. 3 and of every clear daily satellite imagery during July/August/September 2007, we have observed a transition from highly mixed upwelling conditions ( $\sim$ August) to a relaxation period with increasing stratification (early September) when the main upwelling front returned closer to the coast ( $\leq 100 \mathrm{~km}$ ) while large filaments kept on developing offshore (not shown). Note that section EW1 was performed between August $21^{\text {st }}$ and $22^{\text {th }}$ under intense southward winds $(\sim 15 \mathrm{~m} / \mathrm{s})$, whereas they were weak and decreasing $(<5 \mathrm{~m} / \mathrm{s}$ on the $24^{\text {th }}$ of August) when sampling section EW2 $\left(40^{\circ} \mathrm{N}\right)$. The filament was surveyed when equatorward winds have drastically decreased $\left(6-8^{\text {th }}\right.$ September), while they were still imposing a slight offshore Ekman drift in the surface layer. The relatively calm conditions were adequate for filaments development and tracking.

\subsection{Shelf circulation: upwelling currents and mesoscale structures.}

The velocity data analysed in this section are exclusively coming from the 300 kHz LADCP along sections EW1 and EW2 (Fig. 4) and within the filament (Fig. 5). Data from the two vessel mounted ADCP (150 and $38 \mathrm{kHz})$ were however used for cross validation to confirm the circulation patterns discussed below.

A typical upwelling circulation can be identified along every zonal section, although other mechanisms (internal waves or vortices) certainly superimpose their dynamical signature. The typical upwelling circulation is especially marked during leg 1 when the favourable winds were very strong (i.e. EW1 section, Fig. 鿉). Along-shore velocities are mostly southward, intensified at the surface, ranging from -0.1 to -0.15 at the sub-surface to $\sim-0.25 \mathrm{~m} / \mathrm{s}$ or more at the surface (Fig. 价2). 
Although slightly less intense than previous observations, this seems to match the upwelling jet (PCC described by Peliz et al. (2002)). The cross-shore velocities are mostly westward (offshore) at the surface: $\sim-0.05 \mathrm{~m} / \mathrm{s}$ with with some higher peaks locally. It is mostly eastward (onshore) below: $\sim 0.05 \mathrm{~m} / \mathrm{s}$ over the deepest part of the shelf where the upwelling front is found, but reaching sometimes up to $\sim 0.15$ $\mathrm{m} / \mathrm{s}$ within the water column. While the larger patterns are consistent with and can be attributed to the upwelling mechanism, the local extrema are most probably associated with turbulence or internal waves.

Close to the coast, the currents exhibit a more complex pattern, with an onshore flow over most of the water column accompanied with southward (EW1 Fig. 4a 2) or northward currents (EW2 on Fig. 4b2 and filament Fig. 5a2). These features occurring at the inner shelf (within $35 \mathrm{~km}$ from the coast) have a strong barotropic signal with velocities of around $0.1 \mathrm{~m} / \mathrm{s}$ ). Another strong poleward flow was observed during the filament survey, when the upwelling favourable winds have decreased: it is located further offshore $(\sim 40-70 \mathrm{~km})$ and intensified at the surface (up to 0.25 $\mathrm{m} / \mathrm{s}$ ). Poleward flow has been documented along all eastern boundary currents and in the region by (Peliz et al., 2005; Torres and Barton, 2007) who studied the countercurrent IPC. However, given the fact that the poleward current intensified near the shelf break and that it is discontinued in space and time, the present observations are rather associated with mesoscale structures such as vortices or filaments (Relvas et al., 2007).

At the inner shelf, these along-shore alternating flows resulted in a convergence zone at the base of the filament $\left(9.5^{\circ} \mathrm{W} / 40.3^{\circ} \mathrm{N}\right)$ and are consistent with the presence of a dipole, with a cyclonic mesoscale eddy on the northern part (EW1) and an anticyclonic one further south (EW2), promoting the extension of the filament. Sanchez et al. also documented the contribution of strong opposing subsurface flows 
to the generation of filaments at their base. Away from the coast $(40-70 \mathrm{~km})$, the filamental structure is associated with a strong offshore current in the surface layer and an onshore current below (Fig. 5a1), consistent with the westward extension of the filament (Fig. 3a and Fig. 7a).

The North-South section across the tip of the filament ( $\sim 150 \mathrm{~km}$ off the shelf) is used to characterize the importance of accompanying mesoscale structures for its development. A strong surface cyclonic eddy is detected just south of the structure (Fig. [5b), characterized by eastward $\left(0.15 \mathrm{~m} / \mathrm{s}\right.$ at $\left.40.25^{\circ} \mathrm{N}\right)$ and westward velocities $\left(<-0.25 \mathrm{~m} / \mathrm{s}\right.$ at $\left.40.3^{\circ} \mathrm{N}\right)$. A subsurface anticyclonic vortex is observed north of the filament: westward velocities of $0.1 \mathrm{~m} / \mathrm{s}$ located at $40.43^{\circ} \mathrm{N}$ from the surface until $60 \mathrm{~m}$ associated with eastward velocities of $-0.1 \mathrm{~m} / \mathrm{s}$ at $40.45^{\circ} \mathrm{N}(30-60 \mathrm{~m})$. This dipole of coupled cyclonic and anticyclonic eddies located respectively south and north of the filament advects coastal upwelled waters offshore $(-0.1$ to $-0.25 \mathrm{~m} / \mathrm{s})$. Even though other mechanisms could explain these velocity patterns, note that they are consistent with the mushroom shape observed at the tip of the filament (Fig. 7a), typical of dipolar structures. Below the filament (45 to $60 \mathrm{~m}$ ), at $40.375^{\circ} \mathrm{N}$, a counter jet ( $\sim 0.1 \mathrm{~m} / \mathrm{s}$ eastward $)$ is observed and seems related to the subsurface onshore flow, already observed along the EW section (Fig. 5a1), which accompanies and compensates the offshore extension of the filament at the surface (García-Munoz et al., 2005).

Overall, a strong (sub)mesoscale signal superimposes on the large scale classical upwelling flow, in particular due to the formation of eddies and filamental structures and their associated dynamical signatures. This smaller scale signal is indeed particularly clear for both EW2 and filament sections, when the wind had decreased and the main upwelling development was less intense. The offshore export of surface waters within the surveyed filament and its offshore extension are intensified due to 
the dipolar structure at its tip, likely due to flow instabilities. Finer scale variability, cause by internal wave activity (Quaresma et al., 2007) and submesoscale processes (Capet et al., 2008), has been observed but not analyzed in detail. This pictures the following scenario during wind relaxation phases: due to bottom friction, the main upwelling circulation system rapidly decreases above the shelf in shallow water areas, but remains active in regions with larger depths. Mesoscale features, developing at the edge of the offshore upwelling front or directly above the shelf, then dominate the shelf dynamics. Apart from flow instabilities, other mechanisms can be invoked to explain the origin of the (sub)mesoscale signal: local wind variations (Relvas et al., 2007), the signature of local buoyancy forcing as the Western Iberian Buoyant Plume (WIBP) (Peliz et al., 2002) or the interactions of the upwelling jet with bottom topography (Meunier et al., 2010). Our observations do not allow determining the main process responsible for the extreme variability of the shelf circulation, and thus further observational as well as modelling studies are needed.

\subsection{Cross-shore physical variability.}

\subsubsection{Description of the successive upwelling fronts.}

Along EW2 (at $40^{\circ} \mathrm{N}$, Fig. 6b, c, d), a first feature can be identified with a clear uplift of salinity, temperature and density surfaces within $10-20 \mathrm{~km}$ from the coast. This coastal upwelling composed of waters reaching $14^{\circ} \mathrm{C}$ at the surface is likely to result from the most recent pulse of equatorward winds. Considering a westward drift of about $0.05-0.1 \mathrm{~m} / \mathrm{s}$ (see section 3.2), this upwelling front might be "aged" of about 2-4 days. The shelf waters lying on the bottom (i.e. constituting the source waters) are characterized by $\sigma_{\theta} \sim 26.45, \mathrm{~S} \geq 35.75$ and $\mathrm{T} \sim 13.2^{\circ} \mathrm{C}$. These characteristics match the definition of the Eastern North Atlantic Central Water from Subtropical origins (ENACWst), defined by (Varela et al., 2005) as waters with $\mathrm{T}>12.5^{\circ} \mathrm{C}$ and 
$\mathrm{S} \geq 35.7$. Another specific upwelling front is located between $30-50 \mathrm{~km}$, with again clear salinity, temperature and density fronts. It may correspond to a previous wind pulse that occurred 5-8 days ago. Other frontal features, such as the one identified between $65-75 \mathrm{~km}$ from the coast, could either correspond to even older upwelling events (10-15 days) or mesoscale features. The lighter and warmer surface waters $\left(\sigma_{\theta}<26.2\right)$ are pushed offshore (further than $80 \mathrm{~km}$ ) by the Ekman drift associated with the equatorward winds.

Similarly, Rossi et al. (2010) analysed the upwelling dynamics based on section EW1 (at $\left.41^{\circ} \mathrm{N}\right)$ and found that the coastal upwelling was also associated with cold $\left(\leq 13^{\circ} \mathrm{C}\right.$ ) and dense waters $\left(\sigma_{\theta} \geq 27\right)$ within $20 \mathrm{~km}$ from the coast. The previous upwelling fronts were located at $\sim 30-55 \mathrm{~km}$ (also influenced by the secondary upwelling, see Rossi et al. (2010)) and at $65-85 \mathrm{~km}$. The lighter surface waters $\left(\sigma_{\theta} \simeq 26\right)$ were observed further offshore $(>90 \mathrm{~km})$.

The relaxation of the equatorward winds (upwelling favourable) when sampling EW2 as compared to EW1 (see Fig. 2) can be responsible for the small differences observed between these two cross-shore sections. It is also evident that the alongshore variability plays a key role in the IPUS. Indeed, based on a thorough analysis of a T-S diagram using the entire dataset (including a North-South section not presented in this manuscript), Rossi (2010) examined the origins of the upwelled waters along the coast. It was found that the coastal upwelling sources its waters from two different water masses depending on the latitude concerned. Along EW1 (at $41^{\circ} \mathrm{N}$ ), the shelf waters lying on the seabed were characterized by $\sigma_{\theta} \simeq 27.1, \mathrm{~S} \leq 35.7$ and $\mathrm{T}=12.3^{\circ} \mathrm{C}$ (see also Rossi et al. (2010)). They thus matched the description of the Eastern North Atlantic Central Water from Subpolar origins (ENACWsp) as defined by (Varela et al., 2005); whereas the source waters along EW2 (about $100 \mathrm{~km}$ further south than EW1) were identified as ENACWst. Note that instead of a sharp latitudinal 
delimitation, there is probably a gradual transition from ENACWst to ENACWsp around $40-41^{\circ} \mathrm{N}$, so that a mixing between the two end-member of these subsurface water masses might indeed constitute the source of the upwelling in the northern IPUS.

Another feature of interest is the low salinity surface plume $(\leq 35.7)$ observed between 20 and $80 \mathrm{~km}$ from the coast at $41^{\circ} \mathrm{N}$ (EW1, Fig. 6a) whose origin is unclear. Low salinity waters are also found just above the seabed, indicating a possible origin from the deep slope waters (ENACWsp > $150 \mathrm{~m}$ ) being upwelled onto the shelf. Another possible explanation is the influence of the WIBP $(\mathrm{S}<35.7)$ (Peliz et al., 2002) at the northern tip of the IPUS, related to the freshwater discharge from the Galician Rias and Northern Portuguese rivers (the most significant discharges being from the Minho and Douro rivers). However, because of the moderate freshwater input during the upwelling season, the low salinity signal might indeed originate from both the moderate rivers' input mixed with the recently upwelled ENACWsp. Interestingly, the low salinity plume is observed at $40^{\circ} \mathrm{N}$ (EW2, Fig. 6b) between 45 and $80 \mathrm{~km}$, further offshore than along EW1 (Fig. 6a). The thickness of this layer of less saline water $(\sim 30-40 \mathrm{~m})$ is maintained during its south-westward drift by the PC/PCC. However its width had decreased from 60 (EW1) to $35 \mathrm{~km}$ (EW2). Otero et al. (2008) studied the dynamics and extension of this low salinity lens, showing that it is highly influenced by the wind regime and the shelf circulation (i.e. PCC and IPC). The freshwater plume is confined at the coast when poleward winds prevail, whereas it is exported offshore and southward under upwelling favourable wind, as it is the case here. Some studies also emphasized the crucial role this physical feature has on the biological activity, from plankton (Ribeiro et al., 2005) to fish recruitment (Santos et al., 2007). 


\subsubsection{Structure of the mesoscale filament.}

The dimensions of the filament surveyed early September are $\sim 160$ kmin length $\left(\sim 2^{\circ}\right)$ for a coastal base of almost $\sim 100 \mathrm{~km}\left(1^{\circ}\right)$, getting slimmer offshore $\sim 25$ $\mathrm{km}$ (see Fig:7a). The tip of the filament has a mushroom shape, associated with opposite sign submesoscale vortices on each side (see sect. 3.2). The coastal waters, characterized by relatively colder temperature $\left(\sim 16-18^{\circ} \mathrm{C}\right)$ than surrounding $\left(\sim 18-19^{\circ} \mathrm{C}\right)$ are advected till $160 \mathrm{~km}$ offshore. No successive fronts are observed in the filament as compared to EW transects (see sect. 3.3.1). The surface layer constituting the filament is composed of slightly lighter waters (cold and fresh), providing a buoyant input to the structure. In addition, the thermocline is relatively shallow inside the filament and its base reveals vertical displacements of more than $20 \mathrm{~m}$ which may be linked with submesoscale vortices or internal waves (Relvas et al., 2007). The present snapshot does not allow distinguishing between these processes.

The transition between the filament waters and the open ocean is observed at around $160 \mathrm{~km}$ with a deepening of the Mixed Layer Depth (MLD).

On the North-South section carried out about $145 \mathrm{~km}$ offshore, the filament is clearly identified from $40.3^{\circ}$ to $40.45^{\circ} \mathrm{N}$ by local extremes in temperature and salinity both at the surface and the subsurface (Fig. 8a, b). A temperature minimum is observed at the surface ( $\sim 2^{\circ}$ colder than the surroundings), accompanied by a uplift of the thermocline at the subsurface (from $50 \mathrm{~m}$ outside to $35 \mathrm{~m}$ within the filament). The core of the filament is characterized by a surface minimum of salinity ( $\sim 35.75$ down to $50 \mathrm{~m}$, i.e. $\sim 0.1 \mathrm{psu}$ lower than the surroundings) that lies above a sub-surface salinity maximum (>35.9 from 50 to $100 \mathrm{~m}$ ).

The low salinity tongue $(<35.7)$, possibly originating from the coast, is also observed within the filament (Fig. 7b). Likely to be composed of the WIBP mixed 
with the ENACWst/sp recently upwelled, these "fresh" waters have been advected inside the filament up to $140 \mathrm{~km}$ offshore (against $80 \mathrm{~km}$ for the EW section). Consistently, the meridional section across the tip of the structure (Fig] 8 ) revealed a salinity minimum. All our observations agree with Peliz et al. (2002) and suggest that the characteristics of the filament (buoyant waters in its core and the presence of mesoscale eddies at its tips) favour a preferential conduct for exchanges between coastal and offshore waters.

\subsection{Contrasting biological responses.}

\subsubsection{Chlorophyll a distribution from the fluorometer.}

The general satellite-derived chlorophyll $a$ pattern shows maximal concentrations of $1-10 \mathrm{mg} / \mathrm{m}^{3}$ at the coast, while the offshore waters are relatively poor $\sim 0.1$ $\mathrm{mg} / \mathrm{m}^{3}$ or less (Fig. 3a 2 , b2). These two sub-domains are sharply delimited by the upwelling front at $\sim 150 \mathrm{~km}$ off the coast, while mesoscale filaments with moderate surface chlorophyll $a$ concentration $\left(0.1-1 \mathrm{mg} / \mathrm{m}^{3}\right)$ extend up to $\sim 200-300$ $\mathrm{km}$ offshore.

The successive upwelling fronts examined previously along both EW transects (section 3.3.1) are marked with a local surface maxima in chlorophyll $a$, almost equally distributed from the surface down to 30-40 m(Fig. 9a, b). These fronts gradually advected offshore have been analysed by Rossi et al. (2010) along EW1 and are also observed along EW2 (Fig. 9b). The most recent upwelling event is characterized by high chlorophyll $a$ concentrations $\left(1-3 \mathrm{mg} / \mathrm{m}^{3}\right)$ within $20 \mathrm{~km}$ from the coast, then comes the previous one between 30 and $50 \mathrm{~km}$ supporting the highest chlorophyll concentrations $\left(1-10 \mathrm{mg} / \mathrm{m}^{3}\right)$. The maximum response of the ecosystem in terms of chlorophyll $a$ is found over the mid-shelf, developing shortly (about 5-8 days) after the initial upwelling pulse. Finally the most ancient front is found offshore 
between 65 and $75 \mathrm{~km}$ with moderate chlorophyll $a$ content $\left(0.3-1 \mathrm{mg} / \mathrm{m}^{3}\right)$ some 10 to 15 days after the pulse. The ancient front along EW1 also concerns similar chlorophyll $a$ concentrations $\left(0.5-1 \mathrm{mg} / \mathrm{m}^{3}\right)$ and extends until $85 \mathrm{~km}$ against 75 $\mathrm{km}$ for EW2, which correspond to a westward drift of about $10 \mathrm{~km}$ during 3 days. Note that the coastal areas $(<20 \mathrm{~km})$ along EW1 are quite poor in chlorophyll $a$ probably due to the fact that the sampling was carried out exactly during the upwelling pulse.

Between each surface local maxima driven by upwelling pulses, moderate concentrations are observed $\left(0.3-1 \mathrm{mg} / \mathrm{m}^{3}\right)$, associated with a Subsurface Chlorophyll Maximum $(\mathrm{SCM})$ at $\sim 25 \mathrm{~m}$. The ecosystem responds specifically to intense transient upwelling pulses with homogeneous and high chlorophyll $a$ concentrations in the mixed layer. In between these upwelling events, the biological activity is moderate and concentrated at the subsurface. These changes in the chlorophyll $a$ vertical distribution patterns are reflected in the planktonic communities adapted to each particular environmental window (see also sect. 3.5).

Waters westward of the most ancient front $(>80 \mathrm{~km})$ are characterized by a deeper SCM $(\sim 50-70 \mathrm{~m})$ of lower chlorophyll $a$ concentrations $\left(<0.5 \mathrm{mg} / \mathrm{m}^{3}\right)$ and poor surface waters $\left(<0.1 \mathrm{mg} / \mathrm{m}^{3}\right)$.

Overall, chlorophyll $a$ concentrations inside the filament are relatively high $(0.3-$ $\left.3 \mathrm{mg} / \mathrm{m}^{3}\right)$ as compared to surrounding $\left(0.01 \mathrm{mg} / \mathrm{m}^{3}, \mathrm{Fig} / 7 \mathrm{~h} 2\right)$. Shelf concentrations are around $1-10 \mathrm{mg} / \mathrm{m}^{3}$ chlorophyll $a$ within the filament (Fig. 9r), which is similar to the level observed along EW2 but slightly more than along EW1 (1 $\left.3 \mathrm{mg} / \mathrm{m}^{3}\right)$. EW2 and the filament were sampled some days after EW1 while the winds weakened. Restratification after an intense upwelling pulse might allow larger phytoplankton cells to grow and to use more efficiently nutrients brought previously to the euphotic layer. In addition, elevated chlorophyll $a$ concentrations are observed 
within the filament until $160 \mathrm{~km}$ offshore, extending considerably (more than $100 \mathrm{~km}$ ) the surface of biologically productive waters as compared to EW1 and EW2 (85 and $75 \mathrm{~km}$ respectively). Even across the tip of the structure (Fig. 8k), chlorophyll $a$ concentrations are higher within the filament $\left(0.3-1 \mathrm{mg} / \mathrm{m}^{3}\right)$ than outside $(0.1-0.3$ $\left.\mathrm{mg} / \mathrm{m}^{3}\right)$.

Another difference between the filament and the EW sections is the vertical repartition of chlorophyll $a$. Over the inner shelf $(<30 \mathrm{~km})$ the phytoplankton is almost equally distributed within the mixed layer (from the surface down to $40 \mathrm{~m}$ ), whereas a SCM appears at around $40 \mathrm{~km}$, a smaller offshore distance than along EW sections (Fig. 9). The SCM in the filament is situated between 20 to $50 \mathrm{~m}$, following the depth of the thermocline (as indicated by the isotherm $16{ }^{\circ} \mathrm{C}$ on Fig. 9c), varying because of internal waves. It concerns moderate chlorophyll $a$ concentrations $(0.3-1$ $\left.\mathrm{mg} / \mathrm{m}^{3}\right)$ and it is shallower than the deep SCM $(\sim 50-70 \mathrm{~m})$ characterized by lower chlorophyll $a$ levels $\left(0.5 \mathrm{mg} / \mathrm{m}^{3}\right)$ found offshore both EW sections $(>80 \mathrm{~km})$. At about $150 \mathrm{~km}$ off the coast, the SCM still follows the thermocline situated at around $35 \mathrm{~m}$ in the filament, matching a maximum of Coloured Dissolved Organic Matter (CDOM), whereas it is at $50 \mathrm{~m}$ outside (Fig $8 \mathrm{c})$.

Note that within the filament, the successive upwelling pulses are not marked in chlorophyll $a$ as along EW sections, suggesting a relative homogenization of the waters inside the filament.

\subsubsection{Dissolved Oxygen.}

It is worth noting that the minimum of dissolved oxygen $(<200 \mu \mathrm{mol} / \mathrm{kg})$, corresponding to a maximum of $\mathrm{AOU}(>60 \mu \mathrm{mol} / \mathrm{kg}$ ) is found on the shelf bottom, while its lateral position coincides very well with the highest surface concentrations of chlorophyll $a$ (see black isolines on Fig. 9a $, \mathrm{b}, \mathrm{c}$ ). It is a sign of an intense in- 
situ consumption of oxygen by the microbial remineralisation of the sinking organic matter.

Although the horizontal extension of the local minimum of oxygen is quite similar $(\sim 50 \mathrm{~km})$ along both EW sections, its vertical thickness is higher at $40^{\circ} \mathrm{N}$ (up to $70 \mathrm{~m}$ ) than at $41^{\circ} \mathrm{N}$ (less than $50 \mathrm{~m}$ ), consistent with the chlorophyll $a$ distribution. As such, it seems that the intensity of the surface biological activity, related to the amount of sinking organic matter in the water column, is the primary factor driving the local remineralisation processes. However, other important factors are known to influence microbial remineralisation, such as the terrestrial inputs, the alongshore circulation, itself influenced by the width of the shelf (residence time), the benthic processes (Alvarez-Salgado et al., 1997). Note that the near bottom areas with maximum AOU concentrations (up to $>100 \mu \mathrm{mol} / \mathrm{kg}$ ) are also marked by elevated turbidity (not shown). It suggests that resuspension processes from the sediment by tidal currents and internal waves might play a key role in these remineralisation patterns (Alvarez-Salgado et al., 1997; Quaresma et al., 2007).

The local minimum of oxygen below the filament presents the maximal spatial extension (till $\sim 150 \mathrm{~m}$ deep and $60 \mathrm{~km}$ from the coast) and reaches the lowest levels of dissolved oxygen recorded, such as $115 \mu \mathrm{mol} / \mathrm{kg}$ (AOU up to $>110 \mu \mathrm{mol} / \mathrm{kg}$ ). Further offshore (Fig:8c, d), the SCM at $\sim 30$ m matches with a minimum of AOU ( $-15 \mu \mathrm{mol} / \mathrm{kg}$ symbolizing a strong oxygen production by photosynthesis). The signature in $\mathrm{AOU}$ is detectable at the subsurface with a local maximum ( $>35$ $\mu \mathrm{mol} / \mathrm{kg}$ ) doming right under the structure (130-200 m). Although lateral advection might affect the vertical export of organic matter, this observation suggests that the product of the relatively high surface biological production within the core of the filament is also exported deeper in the water column and remineralized. It highlights the importance of such structure for new as well as regenerated production. 


\subsubsection{Dissolved Nutrients.}

Nutrient concentrations in the mixed layer (down to $40 \mathrm{~m}$ ) within the most recently upwelled waters (less than $30 \mathrm{~km}$ from the coastline) range around $10-12$ $\mu \mathrm{mol} / \mathrm{l}$ for nitrate $(\mathrm{Fig}, 10 \mathrm{a}), \sim 1 \mu \mathrm{mol} / \mathrm{l}$ for phosphate and $\sim 6 \mu \mathrm{mol} / \mathrm{l}$ for silicate (not shown). Cravo et al. (2010) compiled several nutrients values from the literature and our values are found in the upper range of their dataset, attesting of the strong upwelling event sampled. Then, in the former upwelling front (30-50 km), they decrease down to $2-5 \mu \mathrm{mol} / \mathrm{l}, 0-0.4 \mu \mathrm{mol} / \mathrm{l}$ and $1-2 \mu \mathrm{mol} / \mathrm{l}$ for nitrate, phosphate and silicate respectively. Finally, more than $65 \mathrm{~km}$ from the coast, the nitrate concentration are below detection levels, whereas low concentrations of silicate $(0.3-0.7 \mu \mathrm{mol} / \mathrm{l})$ and phosphate $(0.1 \mu \mathrm{mol} / \mathrm{l})$ remain (not shown). This gradual nutrient depletion, similarly observed along EW1 (not shown) and within the filament (Fig 10b), is likely to be due to constant phytoplankton uptake along the westward drift of the freshly upwelled waters. The absence of nitrate offshore while silicate and phosphate are still detectable reinforces the fact that nitrate is the limiting factor for primary production in surface waters (Castro et al., 2000; Joint et al., 2001). Another hypothesis that could explain this excess of silicate and phosphate is their preferential remineralisation rate revealed by Alvarez-Salgado et al. (1997).

Note that a significant difference between EW2 and the filament remains in the sub-surface waters $(50-100 \mathrm{~m})$. Moderate nitrate concentrations of $4-7 \mu \mathrm{mol} / \mathrm{l}$ are still observed just below the filament until $120 \mathrm{~km}$ offshore (Fig.10 b), whereas it is less than $3 \mu \mathrm{mol} / \mathrm{l}$ from $70 \mathrm{~km}$ off the coast along EW2 (Fig,10a). It could be related to the maximum of $\mathrm{AOU}$, sign of intense remineralisation processes, that was observed just below the filament in sect. 3.4.2. In addition, the specific circulation underneath the filament's core (Fig. $5 \mathrm{a}$, b) might promote accumulation and in-situ 
remineralisation of organic matter originating from the surface biological production.

Overall, the mean nutrient concentrations off the shelf break below $150 \mathrm{~m}$ (source waters of the upwelling) are about $2 / 3$ of what was measured at the inner shelf bottom, as observed for the three macro-nutrients along transects EW1, EW2 and the filament (Fig,10). It suggests that remineralisation processes account for about $1 / 3$ of the nutrient available for the surface coastal ecosystem. This estimation is in line with Alvarez-Salgado et al. (1997) who showed that nutrient remineralisation tends to increase surface primary production by up to $50 \%$.

\subsection{Comparative analysis of the planktonic communities.}

\subsubsection{Phytoplankton communities.}

The successive upwelling fronts along EW2 are characterized by high phytoplankton biomasses, as shown by 3 peaks of total chlorophyll $a$ (from HPLC) at 15, 41 and $65 \mathrm{~km}$ (Fig. 11 $)$. Shelf communities $(<50 \mathrm{~km}$, associated with the two most recent upwelling fronts) are largely dominated by micro-phytoplankton $(\sim 90 \%)$ in both surface and sub-surface layers (Fig. 11b, c). Cermeno et al. (2006) also observed that microphytoplankton dominates the assemblage during an upwelling event, while nano- and picophytoplankton are present in lower proportions. Surprisingly, both surface and subsurface communities composition changed clearly at the transition between the 2 former upwelling fronts (i.e. at $55 \mathrm{~km}$ ). In contrast with the coastal upwelling communities, they are roughly composed of $50 \%$ of micro-, 25 $\%$ of nano- and $25 \%$ of pico-phytoplankton. Then, the size repartition of plankton within the most ancient front at $65 \mathrm{~km}$ is indeed very similar to the coastal fronts. Although it has a lower chlorophyll $a$ content, probably due to the gradual nutrient depletion during 8 to 10 days after the initial pulse, it is still dominated by microphytoplankton at the surface and the subsurface. Note that the low salinity plume 
(grey contours on Fig. 9b) is constituting the most ancient front but not the coastal one, so that this feature can not solely explained the similar size structure of the phytoplankton. Both open ocean communities $(>80 \mathrm{~km})$ are clearly different and are dominated by small size cells, with a composition of $45 \%$ of pico-, $35 \%$ of nanoand $20 \%$ of micro-phytoplankton at the surface and the subsurface. Note that there is still a small proportion of microphytoplankton, suggesting that passive advection of chlorophyll- $a$ through the front occurs (see also sect. 3.4.1 and 3.6).

Within the filament, the relative proportion of micro-phytoplankton over the shelf (at 26 and $41 \mathrm{~km}$ ) is around $80 \%$, similarly to EW sections (Fig. 12b, c). From $60 \mathrm{~km}$ off the coast $(63,107$ and $151 \mathrm{~km})$, it reduces to $30 \%$ or less , while being replaced by nanoplankton which reaches $\sim 50 \%$ in the surface waters and even more in the SCM. Pico-plankton represents about $25 \%$ of the population everywhere. Such an high proportion of nano-plankton population is not being observed along the EW sections or offshore. It shows that middle size classes of phytoplankton (nano-, including mixotrophs) are favoured within the filament, whereas at a similar offshore distance in open ocean waters, the communities are pico-plankton dominated. Note that the time lag of about 10-15 days between the sampling of the EW sections and the filament added to the decrease of the upwelling favourable winds (see sect. 3.1) may also partly explain the dominance of nanophytoplankton in the filament. However, because of the similarities of the coastal and open ocean sites between these two periods, it might only affect slightly our interpretations. Another noticeable difference between the communities outside the filament $(195 \mathrm{~km})$ and those inside $(151 \mathrm{~km})$ is the proportion of micro-phytoplankton. They are still more abundant in the filament (50 and $25 \%$ at the surface and subsurface respectively) than in the open ocean (25 and 10\%), being brought from the coastal areas within the filament. The pigments concentration from HPLC can also provide broad information about 
the phytoplankton assemblages across the successive fronts. Considering the accessory pigments known to be specific of certain micro-phytoplankton, we observed that the shelf areas are characterized by high concentrations of fuco and peri indicating that diatoms and dinoflagellates dominate the micro-phytoplankton population (Fig. $11 \mathrm{a}, \mathrm{b})$. Note that the maximum of fuco and peri is found slightly offshore the coastal front. These populations of large cells are known to have a relatively slow development (Tilstone et al., 2003; Ras et al., 2008) and thus seem to appear after a slight time lag ( 2-4 days) as compared to the immediate coastal upwelling.

Conversely, Chlo- $b$ concentrations are high close to the coast suggesting an immediate response of green algae. Crytophytes, cyanobacteria and prochlorophytes (xea) are also present in the most recent upwelling front, within $15 \mathrm{~km}$ from the coast. The distribution of volatile halogenated organic compounds was simultaneously investigated in the IPUS by Raimund et al. (2011) and a coastal source was evidenced, possibly related to these near-coastal communities. When moving away from the coast, peri increases when fuco decreases (55 and $64 \mathrm{~km}$ ), suggesting that dinoflagellates predominate over diatoms when nutrient concentrations diminish during the westward drift in the ancient front. This population shift between diatoms and dinoflagellates, of slower development, has been described by Joint et al. (2001) in a lagrangian water mass experiment. Resende et al. (2007) also observed the occurrence of diatoms close to the coast, whereas dinoflagellates are found offshore after the upwelling relaxation when silicate are depleted. These mixotrophs are able to use directly the particulate organic matter, taking advantage on the ageing diatoms. Cyanobacteria and prochlorophytes $(x e a)$ are present everywhere along section EW2 but highest concentrations occur at $55 \mathrm{~km}$, i.e. between the upwelling fronts where a SCM is observed. At the same location $(55 \mathrm{~km})$ and at $64 \mathrm{~km}$ offshore, elevated concentrations of 19-hex represent a population of haptophytes, indicating the pres- 
ence of specific communities between the upwelling fronts and at the transition with the oligotrophic waters. Further than $80 \mathrm{~km}$ from the coast (85 and $92 \mathrm{~km}$ ), the open ocean communities are composed of nano- (haptophytes, 19-hex; green algae, chlo-b) and pico-plankton (cyanobacteria and prochlorophytes, zea). This is in very good agreement with the analysis of Tilstone et al. (2003); Lorenzo et al. (2005) who described the shelf phytoplankton communities as diatoms and dinoflagellates dominated, whereas cyanobacteria are found in the oceanic waters.

Similar conclusions about the phytoplankton assemblages can be drawn from the planktonic community of the filament (Fig. 12a), although some differences remain. In particular, the total chlorophyll $a$ (HPLC) is still significant $150 \mathrm{~km}$ offshore with $0.8 \mathrm{mg} / \mathrm{m}^{3}$, whereas it was below $0.1 \mathrm{mg} / \mathrm{m}^{3}$ from $70 \mathrm{~km}$ along the EW sections, strengthening the results from sect. 3.4.1. Although diatoms and dinoflagellates are present above the shelf, the dinoflagellate population seems larger than along EW2 (up to $0.15 \mathrm{mg} / \mathrm{m}^{3}$ of peri in the filament against $0.05-0.1 \mathrm{mg} / \mathrm{m}^{3}$ along EW2). When moving offshore, these large cells are replaced by smaller ones: cyanobacteria, prochlorophytes (zea, div-chlo-a) and prymnesiophytes (19-hex) increase rapidly (Fig. 12a). Another significant difference is the concentration of 19-hex: it is 0.25 $\mathrm{mg} / \mathrm{m}^{3}$ until $150 \mathrm{~km}$ offshore within the filament but $\leq 0.1 \mathrm{mg} / \mathrm{m}^{3}$ along EW2 from $70 \mathrm{~km})$. These pico- and nano-phytoplankton dominate the communities within the filament, in line with Barbosa et al. (2001) who found that bacterioplankton is around $15 \%$ of the total plankton community production over the shelf, whereas it can reach about $40 \%$ under more oligotrophic conditions in a filament.

Although our analysis focusses on the cross-shore evolution of the phytoplanktonic communities, it is clear that the alongshore advection of the local water masses (see sect. 3.2 and 3.3.1) introduces additional variability not analysed here. 


\subsubsection{Zooplanktonic biomasses.}

The highest zooplankton biomass is found at the coast and decreases when moving offshore (Fig. 11 d and Fig. [12 d, black lines). In near coastal areas $(<30 \mathrm{~km})$, zooplankton is dominated by small individuals among whom copepods represent 70 to $80 \%$ of community biomass (not shown). Small sized copepods are important phytoplankton grazers (Landry and Calbet, 2004) and their intense grazing pressure is likely to participate in the observed reduced phytoplankton biomass near the coast (see sect. 3.4.1 and 3.5.1), as already suggested by Fileman and Burkill (2001).

Large individuals dominate from 30 to $50 \mathrm{~km}$ (Fig. 11d and Fig. 12 d) and constitute a "transitional" community. Zooplankton groups such as Oithona Copepods, Chaetognaths, Bryozoan larvaes, Bivalves and Appendicularians prevail there. The presence of Bryozoan larvaes (meroplankton released by neritic benthic adults) at the mid- and outer-shelf suggests that this zooplankton community originated from the coastal upwelling and have then been gradually exported offshore, in line with our previous analysis (sect. 3.3 and 3.5.1). The presence of Chaetognaths, predators of Copepods (Duró and Saiz, 2000), indicates the establishment of a mature zooplankton community with secondary consumers trophic levels. Within $15-60$ $\mathrm{km}$ from the coast, the micro-phytoplankton, especially diatoms (Fig. 117, red line), responds quickly (2-4 days) to the successive upwelling pulses and dominates the shelf assemblages. These high levels of microphytoplankton biomass may contribute to sustain the longer development of the large zooplankton organisms during their offshore drift, explaining why they dominate only from $\sim 30 \mathrm{~km}$ (i.e. about $5-10$ days after the initial pulse). This is in good agreement with Queiroga et al. (2005) who also documented the apparition of both meroplankton and planktonic predators during the offshore displacement of a coastal zooplanktonic community in the 
upwelling season.

Note that large zooplankton organisms are still observed as far as $150 \mathrm{~km}$ offshore within the filament $\left(\sim 100 \mathrm{~mm}^{3} / \mathrm{m}^{3} \mathrm{BV}\right.$, Fig. 12 $\left.\mathrm{d}\right)$, whereas they were completely absent from $70 \mathrm{~km}$ along EW2 (Fig. 11d). the frontal structure (EW1, EW2) seems to strongly isolate large zooplankton individuals from the open ocean (Landry et al. (2012) and references therein), so that the location of the upwelling front (itself driven by the successive pulses of equatorward winds) may set the maximal offshore extension of these large organisms which are an important food source for exploited higher trophic levels. Unfortunately, the lack of sampling at high spatial resolution near the physical boundary does not allow us to conclude firmly. It also shows that the "transitional" community drift further offshore and thus develop a longer time within the filament than along the EW1/EW2 transect, where it is confined between the mid-shelf and the most offshore upwelling front $(\sim 70 \mathrm{~km})$.

Additional HPLC pigments such as phaeo-a (senescent diatoms) and chloid-a (grazer fecal pellets) were exceptionally measured on a subset of the filament samples. Both pigments are found in elevated concentrations until $60 \mathrm{~km}$ (Fig. 12a) indicating that large zooplankton grazers feed on micro-phytoplankton. Their concentrations decrease when moving offshore but level of chloid-a remains slightly higher within the filament $\left(\geq 0.1 \mathrm{mg} / \mathrm{m}^{3}\right)$ than in the open ocean $\left(\sim 0.06 \mathrm{mg} / \mathrm{m}^{3}\right.$ at $\left.195 \mathrm{~km}\right)$. It indicates a more intense zooplankton grazing within the filament than in the open ocean, proof of a dynamical ecosystem exported offshore within the structure.

The offshore oligotrophic ecosystem is characterized by low biomass of small organisms $(>70 \mathrm{~km}$ for EW2 on Fig. 11d and $>160 \mathrm{~km}$ for the filament on Fig. [12d), essentially composed of $\sim 50 \%$ of small Copepods and $\sim 50 \%$ of Cladocera (not shown). In the open ocean (offshore the main front and outside the long filaments), the size-structure of the oligotrophic ecosystem seems in equilibrium 
with both phyto- and zooplankton communities dominated by small organisms.

\subsection{Estimation of offshore transport and chlorophyll fluxes.}

In this section, we calculate estimates of offshore transport and chlorophyll fluxes through the filament and across the upwelling front based on a typical situation of the north-western Iberian margin during upwelling season (see Fig. 3b1). The upwelling front extends meridionally from $\sim 37^{\circ} \mathrm{N}$ to $\sim 43.5^{\circ} \mathrm{N}(720 \mathrm{~km})$ and is interrupted by four large filaments. In approximation, the system can thus be separated into 4 filaments, each having about $70 \mathrm{~km}$ width, and a more regular quasi-meridional semi-continuous front extending over $440 \mathrm{~km}$.

The currents derived from the LADCP at $10.6^{\circ} \mathrm{W}$ (see Fig. 5b) allow us to evaluate the offshore transport induced by the filament at its tip. Using the horizontal boundaries from $40.3^{\circ}$ to $40.45^{\circ} \mathrm{N}$ with a vertical extension of $50 \mathrm{~m}$, a westward transport of $\sim 0.16 \mathrm{~Sv}$ due to the filament is estimated. This falls within the lower range of the compilation of observations of upwelling filaments by Sanchez et al., probably because the transport is computed at the tip of the filament. By multiplying the westward velocities by the chlorophyll content (averaging to $0.55 \mathrm{mg} / \mathrm{m}^{3}$ ), a flux of chlorophyll of around $0.016 \mathrm{mg} \mathrm{m}^{-2} \mathrm{~s}^{-1}$ is obtained. Integrating this value over its cross-section ( $50 \mathrm{~m}$ for $0.15^{\circ}$ of latitude) yields to about $82.5 \mathrm{~g} / \mathrm{s}$ of chlorophyll a transported offshore at the tip of the filament, in very good agreement with the flux of $70.7 \mathrm{~g} / \mathrm{s}$ calculated by García-Munoz et al. (2005) in the Canary upwelling system.

To approximate the cross-shore transport of near-coastal water masses due to this structure, we consider the westward velocities recorded at the tip of the filament as similar to the ones during its initiation $(\sim 0.11 \mathrm{~m} / \mathrm{s})$. In addition, we integrate Chlorophyll $a$ concentrations from the coastal areas $\left(\sim 1 \mathrm{mg} / \mathrm{m}^{3}\right)$ over the dimensions 
deduced previously $(70 \mathrm{~km}$ width for a thickness of $50 \mathrm{~m}$ ). It is found that about 0.4 $\mathrm{kg} \mathrm{s}^{-1}$ of chlorophyll $a$ can be exported off the shelf by this single filament. Although all variables (dimensions, velocities and chlorophyll $a$ concentration) are time and space dependent, this number is consistent with other estimates of offshore transport of biogeochemical properties as given bv Alvarez-Salgado et al. (2001): García-Munoz et al. (2005); Alvarez-Salgado et al. (2007); Cravo et al. (2010). The seaward flux of chlorophyll through the surveyed filament can be multiply by 4 to estimate the "filament contribution" to cross-shore transport under a typical upwelling favourable season. It is of the order of $2 \mathrm{~kg} \mathrm{~s}^{-1}$ of chlorophyll $a$ exported from the shelf toward the open ocean by filamental structures over the north-western Iberian margin.

Similar seaward transport estimates can be done through the regular upwelling front. The westward velocities are of the order of $0.05 \mathrm{~m} / \mathrm{s}$ on average over the Ekman layer of about $50 \mathrm{~m}$ thick. By multiplying the westward velocities with the chlorophyll content over the shelf $\left(\sim 1 \mathrm{mg} / \mathrm{m}^{3}\right)$ and integrating this value over the front $(50 \mathrm{~m}$ deep for a length of $440 \mathrm{~km}$ ), it is found that a flux of more than 1 $\mathrm{kg} / \mathrm{s}$ of chlorophyll $a$ is occurring from the shelf toward the open ocean through the front between $37^{\circ} \mathrm{N}$ to $43.5^{\circ} \mathrm{N}$.

Although these calculation contains numerous biases and approximations, it gives an estimate of the cross-shelf exchanges mediated by both structures within the Iberian Upwelling System. Covering only 40\% of the total length of the upwelling front, the filaments are responsible of more than $60 \%$ of the cross-shelf transport, due to the intense offshore advection of coastal ecosystem. In addition, these filamental structures can transport coastal water masses further offshore $(>200 \mathrm{~km})$ than through the upwelling front. We hypothesised that under intense upwelling pulses, the front has a large impact on the cross-shore transport, whereas the effect of selfpropelled filaments become dominant under relaxation period. 


\section{Conclusions.}

During the MOUTON multidisciplinary survey in August/September 2007, strong equatorward winds promoted upwelling development with temperature dropping below $13^{\circ} \mathrm{C}$ at the coast and chlorophyll $a$ concentrations increasing up to $10 \mathrm{mg} / \mathrm{m}^{3}$. The cross-shore gradient was examined by comparing two East-West transects through the upwelling front and one survey of a mesoscale filament.

Our analysis emphasized the role of mesoscale features such as eddies and filaments that superimpose their dynamical signature on the classical upwelling flow. Nevertheless, surface velocities often directed to the west produce a significant offshore transport through the meridional upwelling front. This transport is intensified within the filament surveyed due to the presence of mesoscale dipolar eddies at the base and tip of the elongating structure.

The EW sections are marked by sharp temperature fronts due to the successive upwelling pulses that bring cold/fresh/enriched waters (ENACWsp and ENACWst) to the coast. These consecutive fronts, characterized by elevated chlorophyll $a$ concentrations in the mixed layer, are gradually advected (south)westward by the upwelling currents. During relaxation phases (between fronts), the biological activity is concentrated at the subsurface and still concerns higher levels than in the oligotrophic waters observed from $80 \mathrm{~km}$ off the coast.

Composed of the recently upwelled ENACW mixed with the WIBP, low salinity waters provide a buoyancy input to the filamental structure promoting its offshore elongation. In contrast with EW sections, the water is relatively homogeneous within the 3 dimensional filamental structure but well isolated from the surrounding. The resulting biological response is organised as a shallower subsurface maximum extending far offshore (up to $160 \mathrm{~km}$ ). High surface chlorophyll $a$ concentrations are 
associated with low oxygen levels at the subsurface, a sign of nutrient remineralisation processes that are favoured below the filament.

The variability of water mass properties, including their stratification, nutrient contents and maturation state, is impacting strongly the planktonic communities. Coastal areas $(<20 \mathrm{~km})$ support a quick response of small phytoplankton, followed 2-4 days later by micro-phytoplankton which dominate largely the coastal upwelling. The zooplankton population at the coast is mainly composed of numerous small copepods imposing a high grazing pressure and associated with a strong export of organic matter. Slightly offshore (between 30 to $60 \mathrm{~km}$, i.e. 5-10 days), dinoflagellates gradually overshadow diatoms while large individuals of zooplankton dominate. Being relatively isolated for a longer offshore drift, the coastal ecosystems embedded inside the filament evolve differently. Coastal waters are also dominated by micro-phytoplankton but higher proportions of nano-plankton are observed in the filament $(>60 \mathrm{~km})$ due to the nutrient depletion promoting mixotrophy. Strongly contrasting with the coastal and transitional areas, oligotrophic assemblages found offshore are characterized by small-size individuals and low biomasses for both zooand phytoplankton.

Comparing the hypothetical cross-shore transport mediated by the two structures, it is shown that filaments, although less extended meridionally than the upwelling front, are responsible of a greater offshore flux of chlorophyll. Due to their specific physical structures, filaments act as preferential conducts for seaward transport of productive coastal waters. We speculate that upwelling fronts, regularly pushed offshore by transient favourable winds, have a large importance in cross-shelf exchange at short time scales, whereas the effect of filaments dominates under relaxation period, maintaining a constant fuelling of the oligotrophic open ocean.

To further estimate the role of prominent filamental structures on the metabolic 
balance of the North-Atlantic gyre, extensive observations must be carried out. Constant monitoring through an integrated marine observing system (including moored buoys, regular glider deployments, high frequency radars and ship-based survey) could be implemented at specific locations in the IPUS where the formation of such filaments is favoured (e.g. capes, promontory). Another important project is to pursue the development of 3D coupled models at high resolution of the IPUS, whose validation could obviously benefit from the present results.

\section{Acknowledgements.}

V.R. was supported by a PhD Grant from DGA. V.G. acknowledges funding support from CNES. V.R. and Y.M. gratefully acknowledge the "Pourquoi pas?" crew (GENAVIR) and SHOM technical staff for their professionalism and involvement during the MOUTON2007 campaign at sea. The authors also thank the trainees from IUEM involved in the work at sea. This study is a contribution to SHOM project MOUTON funded by DGA (PEA012401) and the French Navy. The authors also acknowledge D. Thouron (LEGOS) for nutrient analysis, J. Ras and H. Claustre (LOV) for double pigments analysis, A. Paulmier (LEGOS) for fruitful discussion. Many thanks to A. Goubanova and D. Altukhov (IBSS, Sevastopol, Ukrain) for Zooplankton manual counting and identification, as well as to M. Vernet (CNRS, Roscoff) for CHN analysis. V.R. was partly supported by an Australian Research Council Grant while finishing this paper. The authors would like to thank the anonymous reviewers for their valuable comments that have substantially improved the manuscript. 


\begin{tabular}{|c|c|c|c|}
\hline HPLC measured pigments & Abbreviations & Size classes & Taxonomic or biogeochemical significance \\
\hline Chlorophyll a & chlo- $a$ & All & All - except Prochlorophytes \\
Chlorophyll b & chlo-b & $\mathrm{P}+\mathrm{N}$ & $\begin{array}{c}\text { Green algae } \\
\text { (Chlorophytes, Prasinophytes) }\end{array}$ \\
Peridinin & peri & $\mathrm{M}$ & Dinoflagellates \\
Fucoxanthin & fuco & $\mathrm{M}$ & Diatoms, Prymnesiophytes, \\
& & & and some Dinoflagellates \\
Zeaxanthin & $z e a$ & $\mathrm{P}$ & Cyanobacteria, Prochlorophytes \\
Alloxanthin & allo & $\mathrm{P}+\mathrm{N}$ & Cryptophytes \\
$19-$ Butanoyloxyfucoxanthin & $19-$ but & $\mathrm{N}$ & Prymnesiophytes, Pelagophytes \\
Hexanoyloxyfucoxanthin & $19-$ hex & $\mathrm{N}$ & Prymnesiophytes (Haptophytes) \\
Divinyl Chlorophyll a & div-chlo-a & $\mathrm{P}$ & Prochlorophytes \\
Chlorophyllide a & chloid-a & - & Senescent diatoms \\
Phaeophorbide a & phaeo-a & - & Grazor fecal pellets \\
\hline
\end{tabular}

Table 1: List of the pigments used in this study and their taxonomic significance. A few characteristic pigments (bold letters) were associated to particular algal groups to describe the phytoplankton community, following Ras et al. (2008). The last four pigments were additionally measured on a small subset of the total samples. 


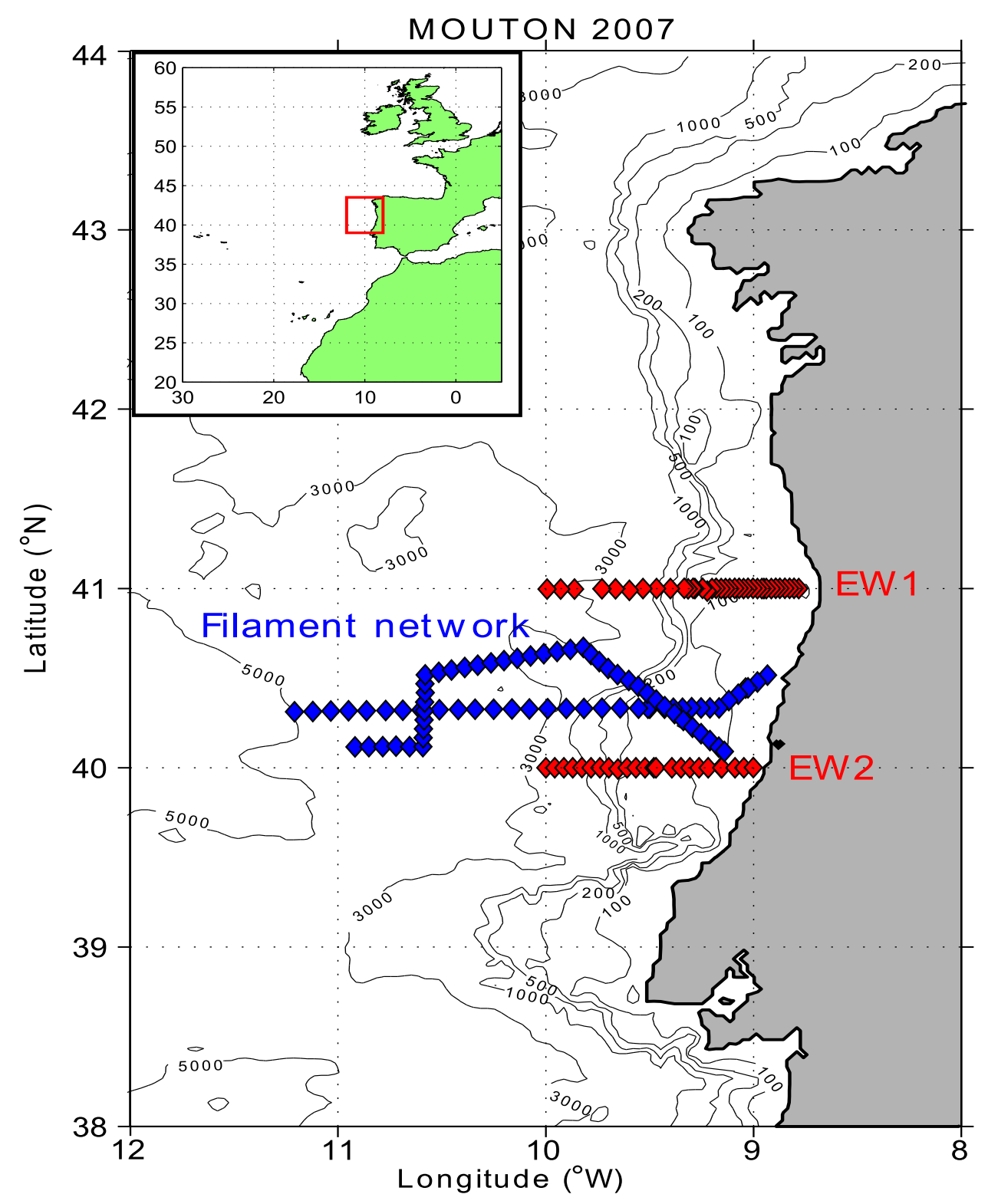

Figure 1: Overview of the MOUTON 2007 oceanographic campaign in the Iberian Peninsula Upwelling System. Colored diamonds represent the CTD stations organised as transects (red for East-West sections: EW1 at $41^{\circ}$ and EW2 at $40^{\circ}$; blue for the filament network). Black contours represent the bathymetry (in m). A map of south-western Europe and north Africa is displayed on the upper left insert, with a red rectangle highlighting the surveyed area. 

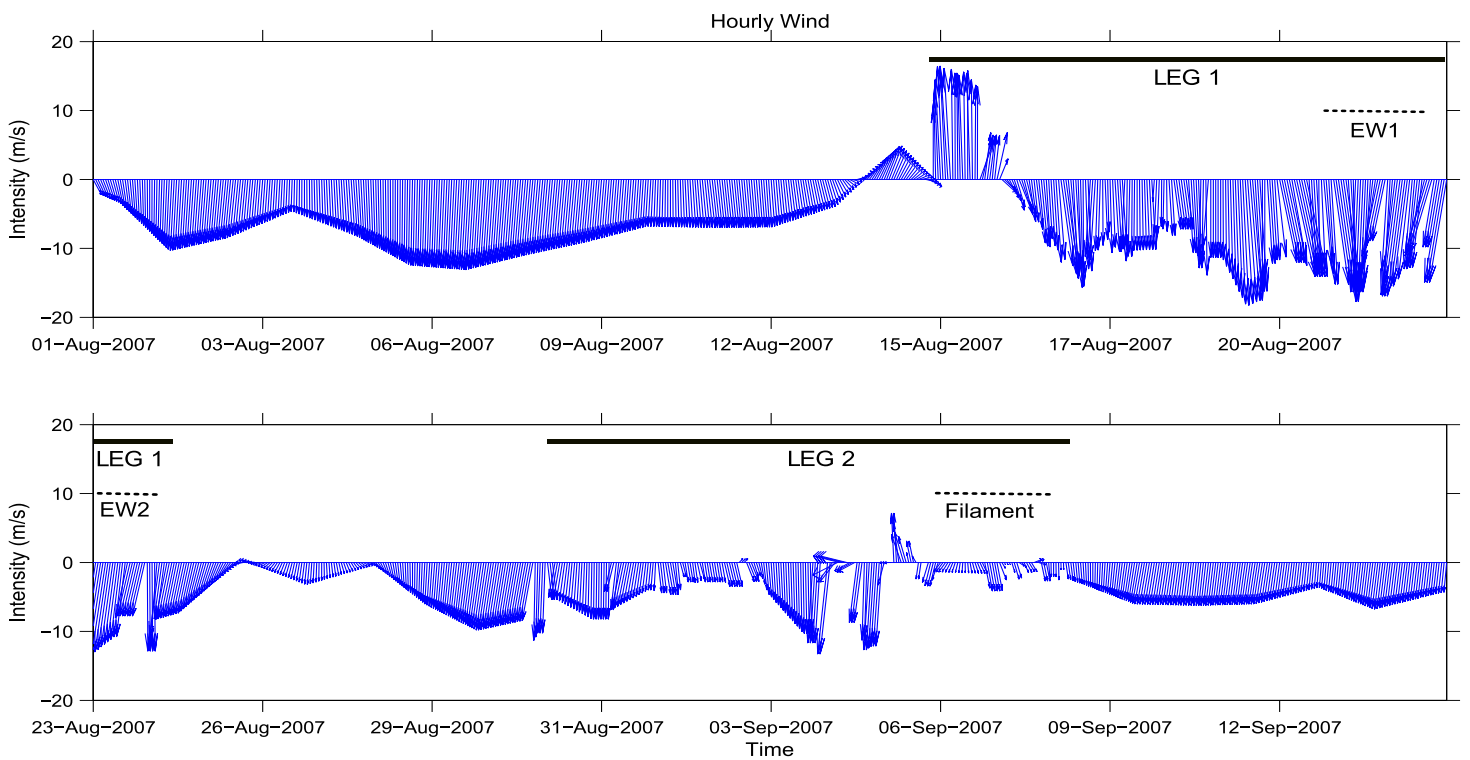

Figure 2: Wind (in $\mathrm{m} / \mathrm{s}$ ) vectors from the QuikSCAT scatterometer (averaged over the surveyed area $39-43^{\circ} \mathrm{N} / 9-12^{\circ} \mathrm{W}$ ) and the onboard measurements (during both legs of the survey, as shown by the black segments). Black dotted segments indicate when the transects of interest were carried out. The wind vectors emanate from equally spaced points along the horizontal x-axis, while the vector components are expressed relative to the origin of the respective vector. The vectors pointing down (up, respectively) represent a wind blowing southward (northward, respectively) of intensity directly readable on the y-axis. 

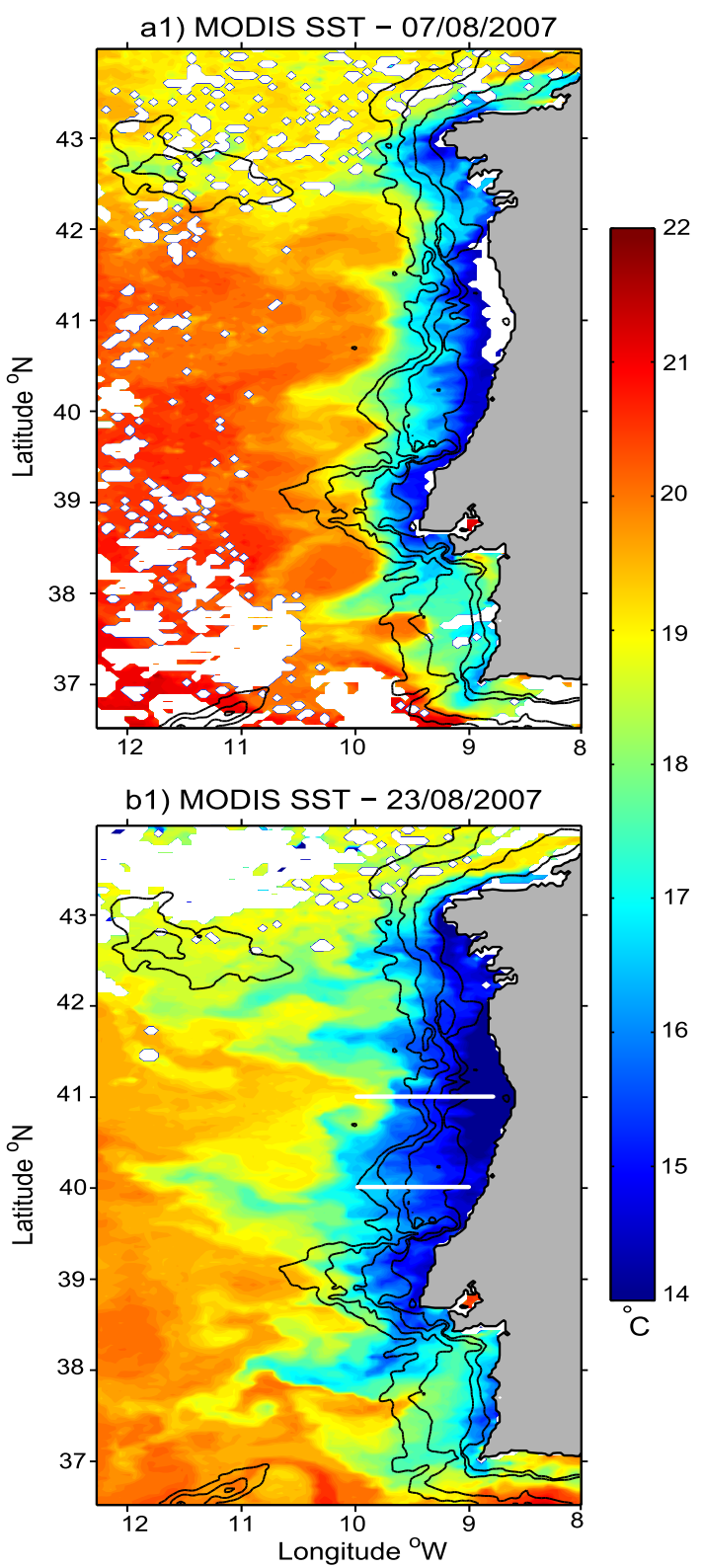

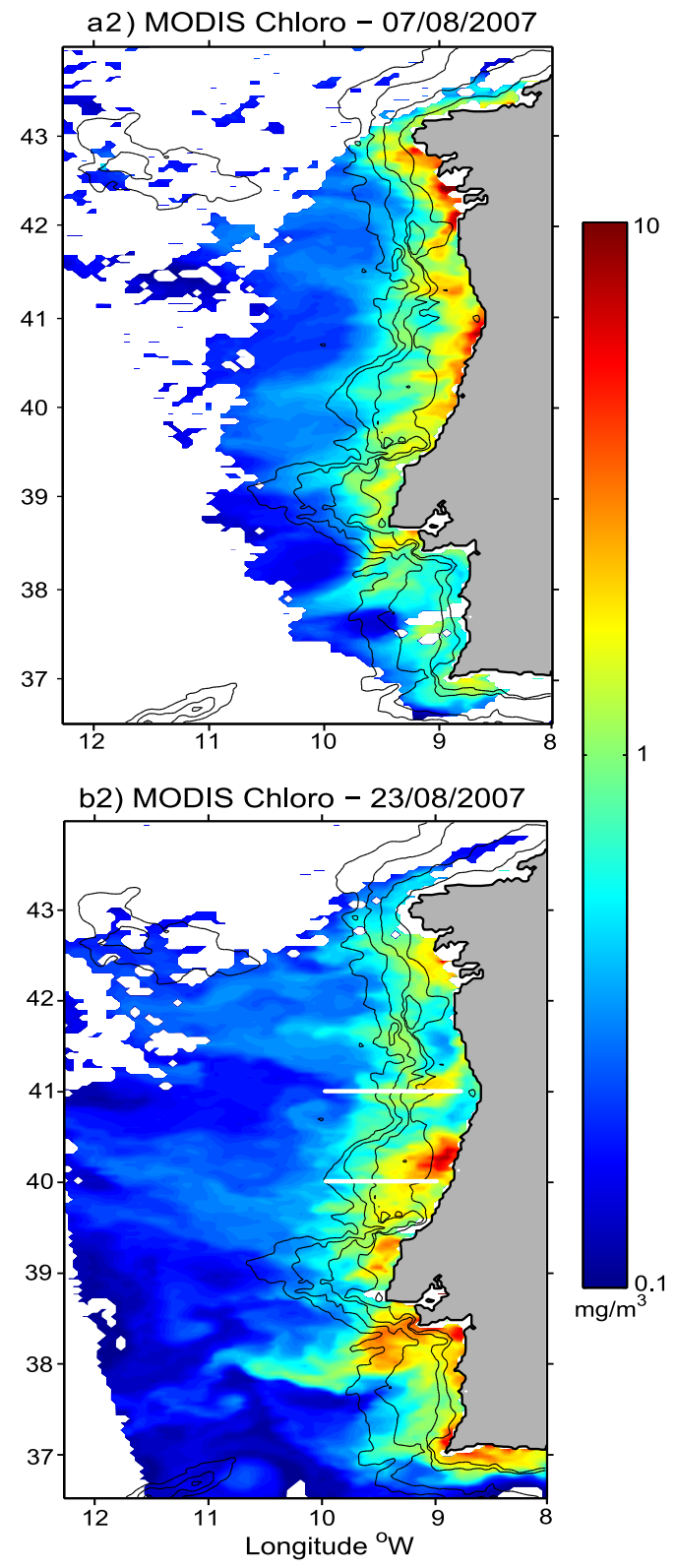

Figure 3: Daily Sea Surface Temperature $\left({ }^{\circ} \mathrm{C}\right)$ and Chlorophyll- $a\left(\mathrm{mg} / \mathrm{m}^{3}\right)$ from MODIS Aqua for a) $7^{\text {th }}$ August 2007 and b) $23^{\text {rd }}$ August 2007. White areas are clouds and black contours represent the bathymetry (200, 500, 1000 and $2000 \mathrm{~m})$. On lower panels b1) and b2), the white segments represent the cross-shore sections EW1 and EW2. 

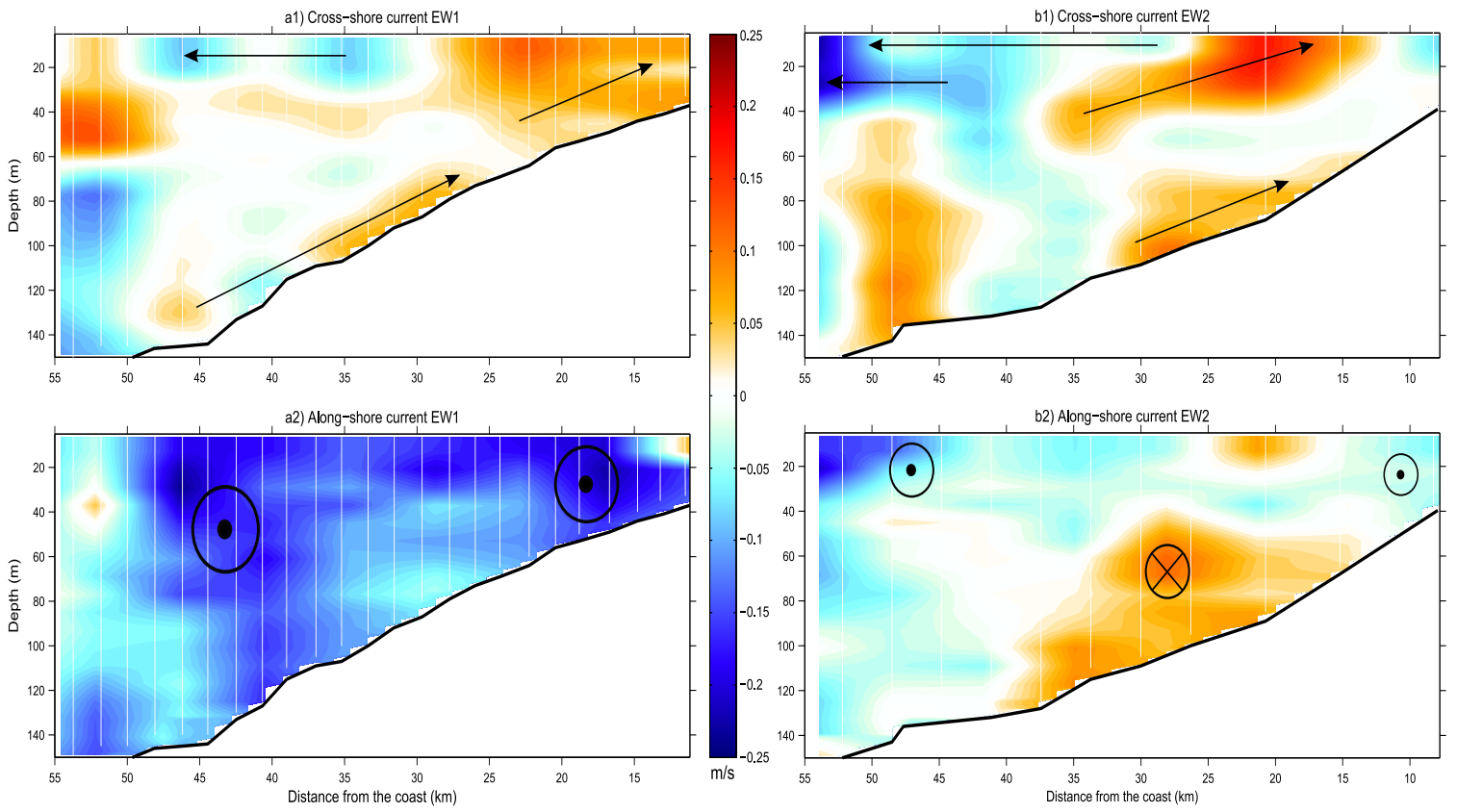

Figure 4: Cross-shore (a1, b1) and along-shore (a2, b2) velocities $(\mathrm{m} / \mathrm{s})$ derived from the LADCP along EW1 at $41^{\circ} \mathrm{N}$ (a) and EW2 at $40^{\circ} \mathrm{N}$ (b). On the upper panels blue color indicates westward/offshore current and red color eastward/onshore. On the lower panels, red color represent northward current and blue color southward. The white thin lines indicate the measurement positions; the thick black lines represent the observed bathymetry. The black annotations represent an illustrative sense of the circulation. 

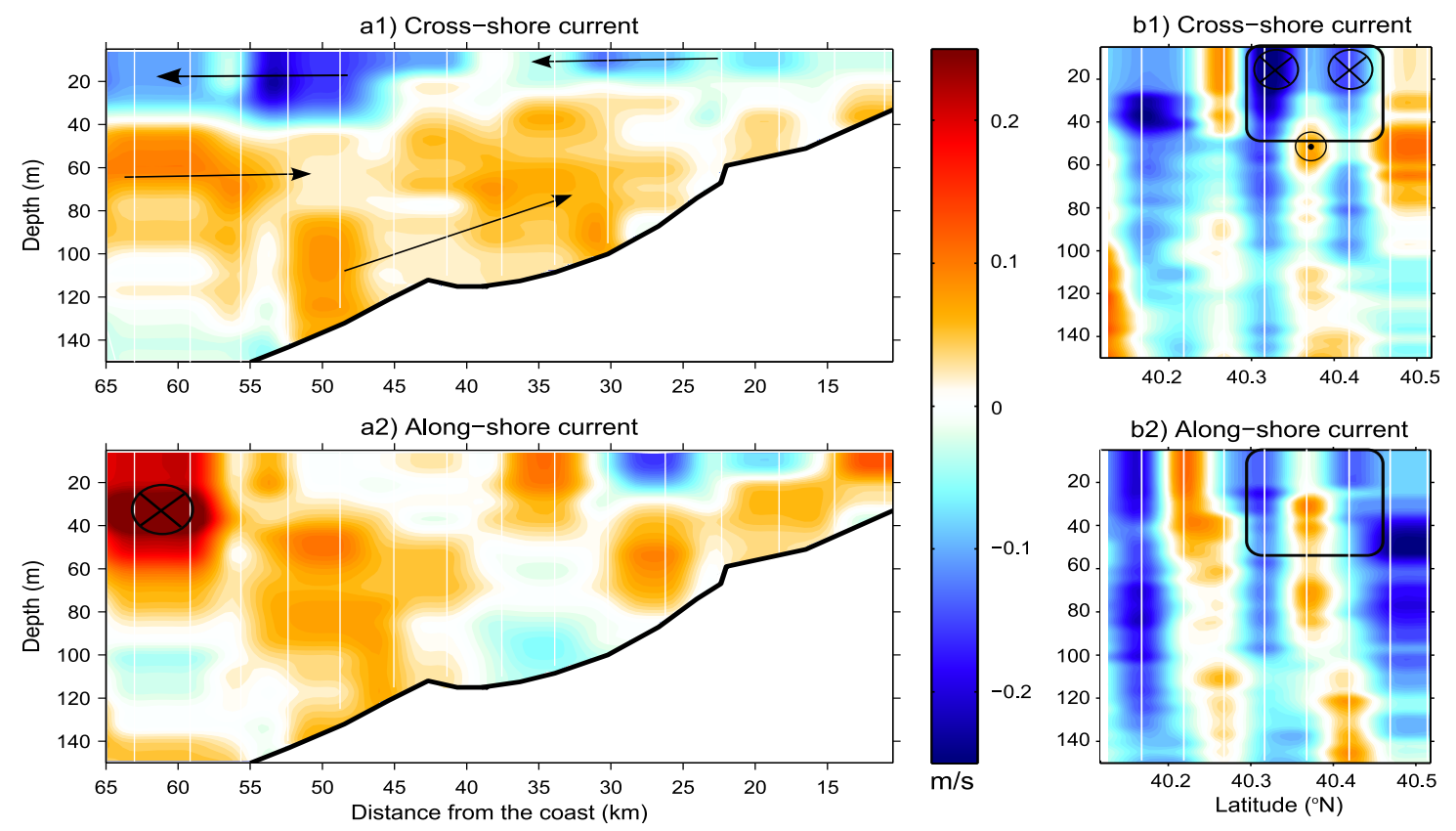

Figure 5: Cross-shore (a1, b1) and along-shore (a2, b2) velocities $(\mathrm{m} / \mathrm{s})$ derived from the LADCP along the East-West transect within the filament (a) and the North-South section across its tip at $10.6^{\circ} \mathrm{W}$ (b). On the upper panels blue color indicates westward/offshore current and red color eastward/onshore. On the lower panels, red color represent northward current and blue color southward. The white thin lines indicate the measurement positions; the thick black lines represent the observed bathymetry; the black rectangles identify the core of the filament. The black annotations represent an illustrative sense of the circulation. 

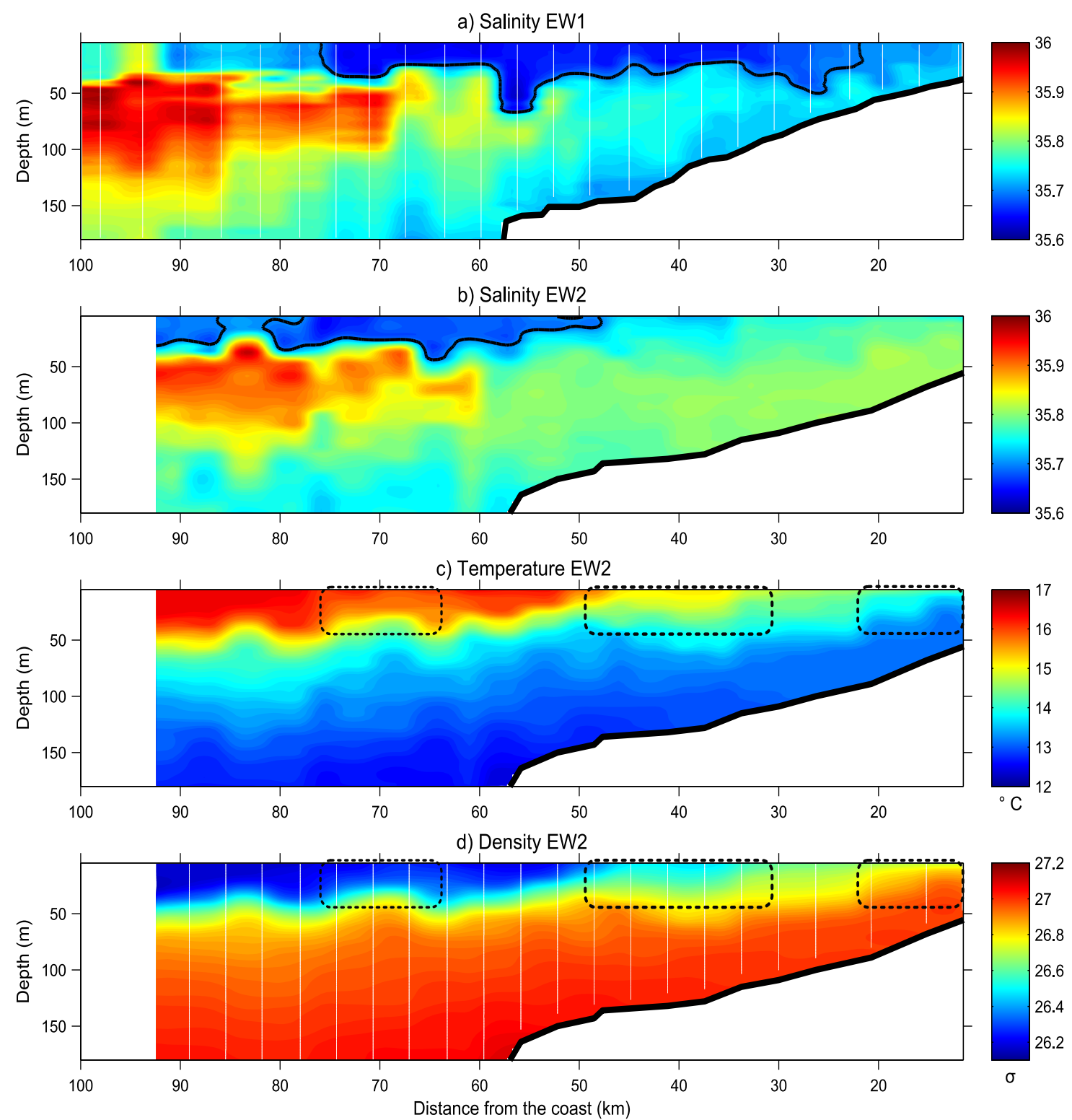

Figure 6: Distance from the coast $(\mathrm{km})$ versus depth profiles of CTD sensors along both cross-shore transects. a) EW1 salinity; b) EW2 salinity, c) temperature $\left({ }^{\circ} \mathrm{C}\right)$ and d) density $\left(\sigma_{\theta}\right)$. The black lines in the salinity sections contour the low salinity plume $(<35.7)$. The white vertical lines in $d)$ indicate the measurement positions; the thick black line represents the observed bathymetry. Black dotted rectangles on panel c and d identify the successive upwelling fronts. 

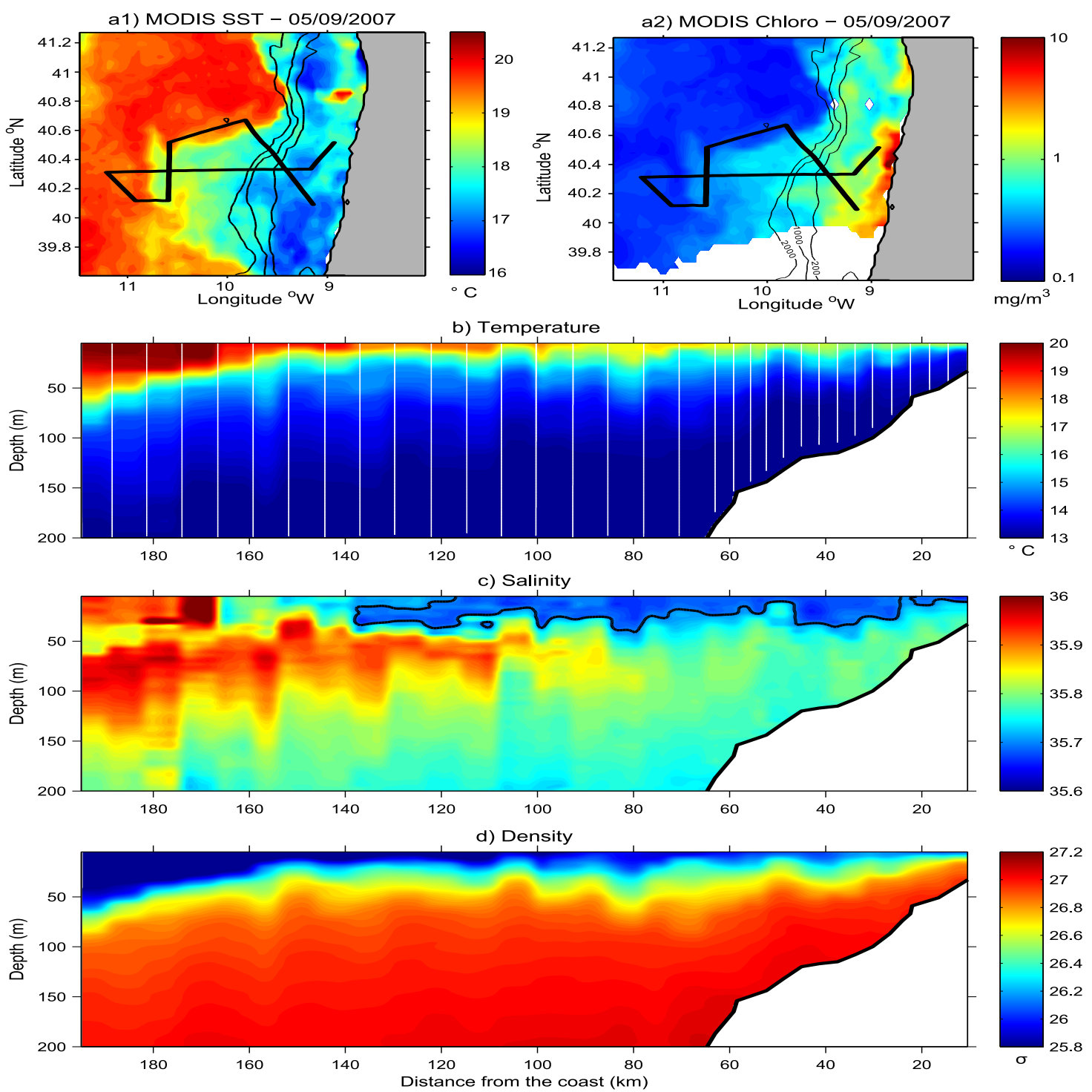

Figure 7: a1) SST $\left({ }^{\circ} \mathrm{C}\right)$ and a2) chlorophyll $a$ concentration $\left(\mathrm{mg} / \mathrm{m}^{3}\right)$ from MODIS Aqua on $5^{\text {th }}$ September 2007. The black thick lines represent the filament network. Distance from the coast $(\mathrm{km})$ versus depth profiles of CTD sensors for the EW transect within the filament b) temperature in ${ }^{\circ} \mathrm{C}, \mathrm{c}$ ) salinity and d) density. Black contours in the salinity section indicates the low salinity plume $(<35.7)$. The white vertical lines in $\mathrm{b})$ indicate the measurement positions; thick black lines represent the observed bathymetry. 

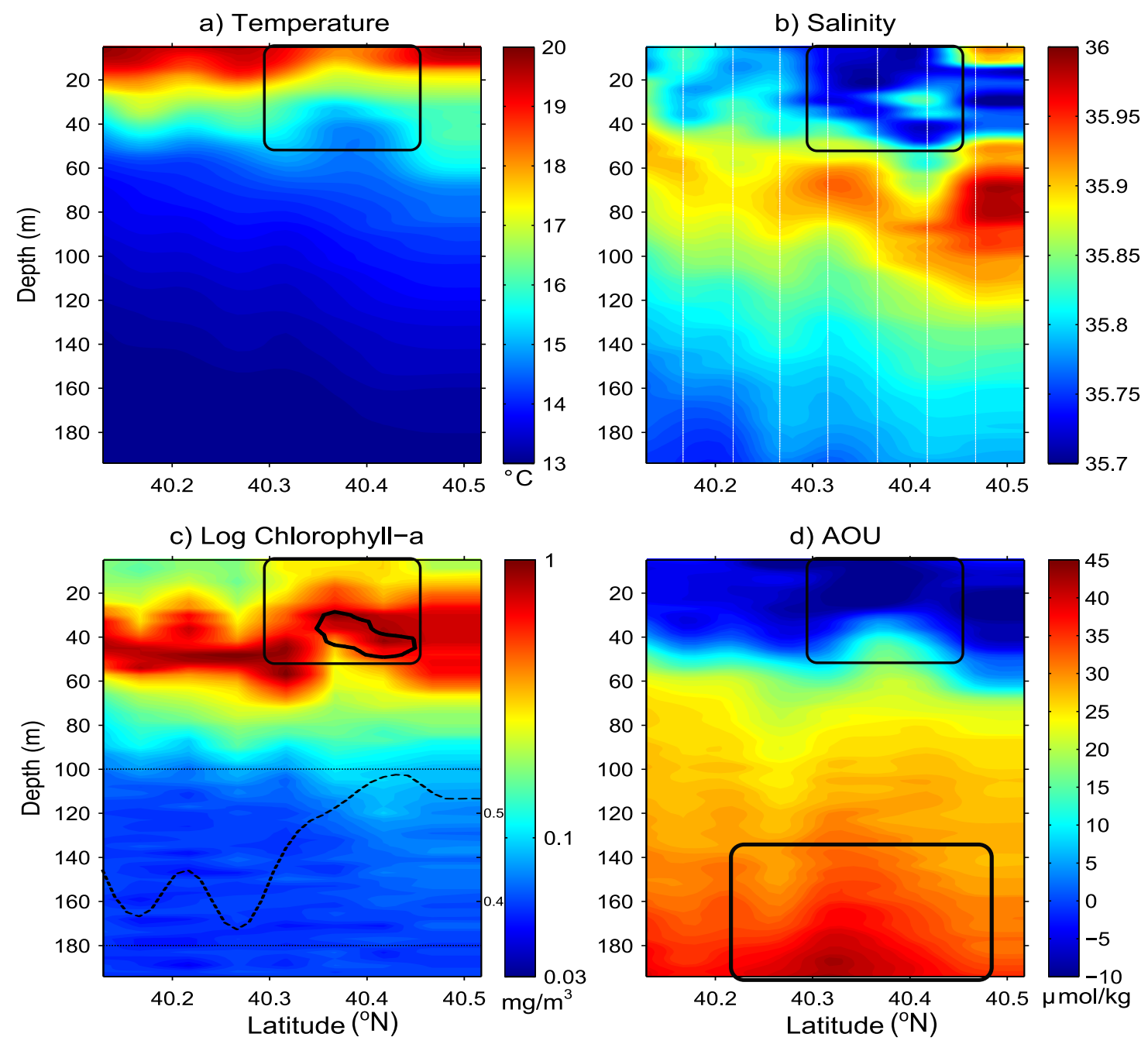

Figure 8: All data are from the NS transect across the tip of the filament at $10.6^{\circ} \mathrm{W}$. Latitude versus depth profiles of CTD sensors: a) temperature $\left({ }^{\circ} \mathrm{C}\right)$, b) salinity, c) chlorophyll $a$ concentrations from the fluorometer (converted in $\mathrm{mg} / \mathrm{m}^{3}$ ) and $\mathrm{d}$ ) $\mathrm{AOU}(\mu \mathrm{mol} / \mathrm{kg}$ ). Black contour in c) indicates the maximum of Colored Dissolved Organic Matter measured from another fluorometer. The black dotted line inserted in c) represent the vertically averaged chlorophyll $a$ concentrations in the top 50 meters (ranging from 0.35 to $0.55 \mathrm{mg} / \mathrm{m}^{3}$, as indicated on the right $\mathrm{y}$-axis). The white vertical lines in b) indicate the measurement positions; the black rectangles at the surface of a, b, c, d) identify the core of the filament, while the additional one in d) identifies a maximum of AOU under the structure. 

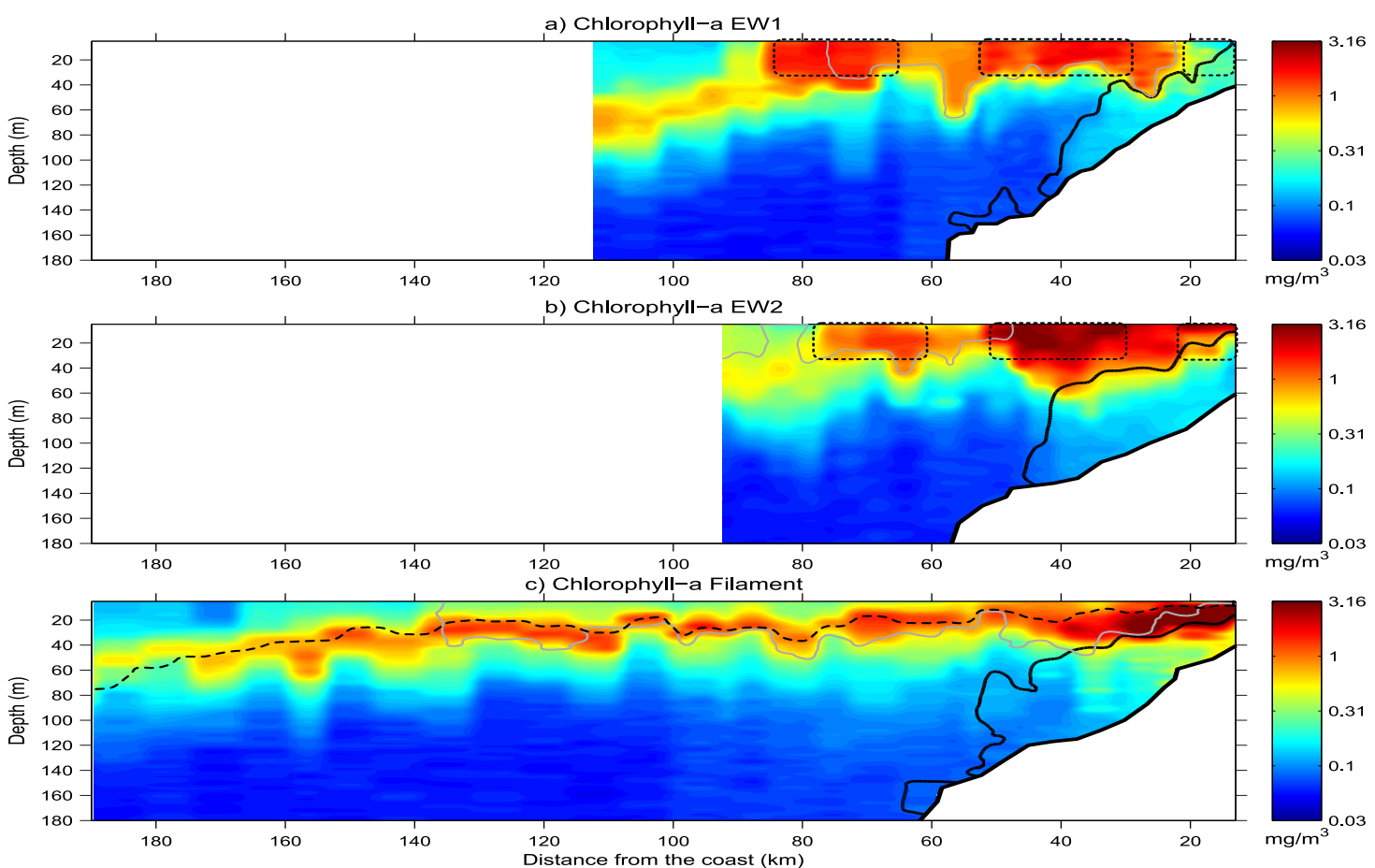

Figure 9: Distance from the coast $(\mathrm{km})$ versus depth profiles of chlorophyll $a$ concentrations (from fluorometer, converted in $\mathrm{mg} / \mathrm{m}^{3}$ ) along a) EW1 b) EW2 and c) EW within the filament. Black contours on the profile indicate the maximum of AOU concentrations ( $>60 \mu \mathrm{mol} / \mathrm{kg}$, corresponding roughly to dissolved oxygen concentrations $<200 \mu \mathrm{mol} / \mathrm{kg}$ ). Grey contours close to the surface represent the low salinity plume $(<35.7)$. The black dotted line on panel c represent the isotherm $16^{\circ} \mathrm{C}$. Black dotted rectangles on panel a and b identify the successive upwelling fronts. The thick black lines represent the observed bathymetry. 


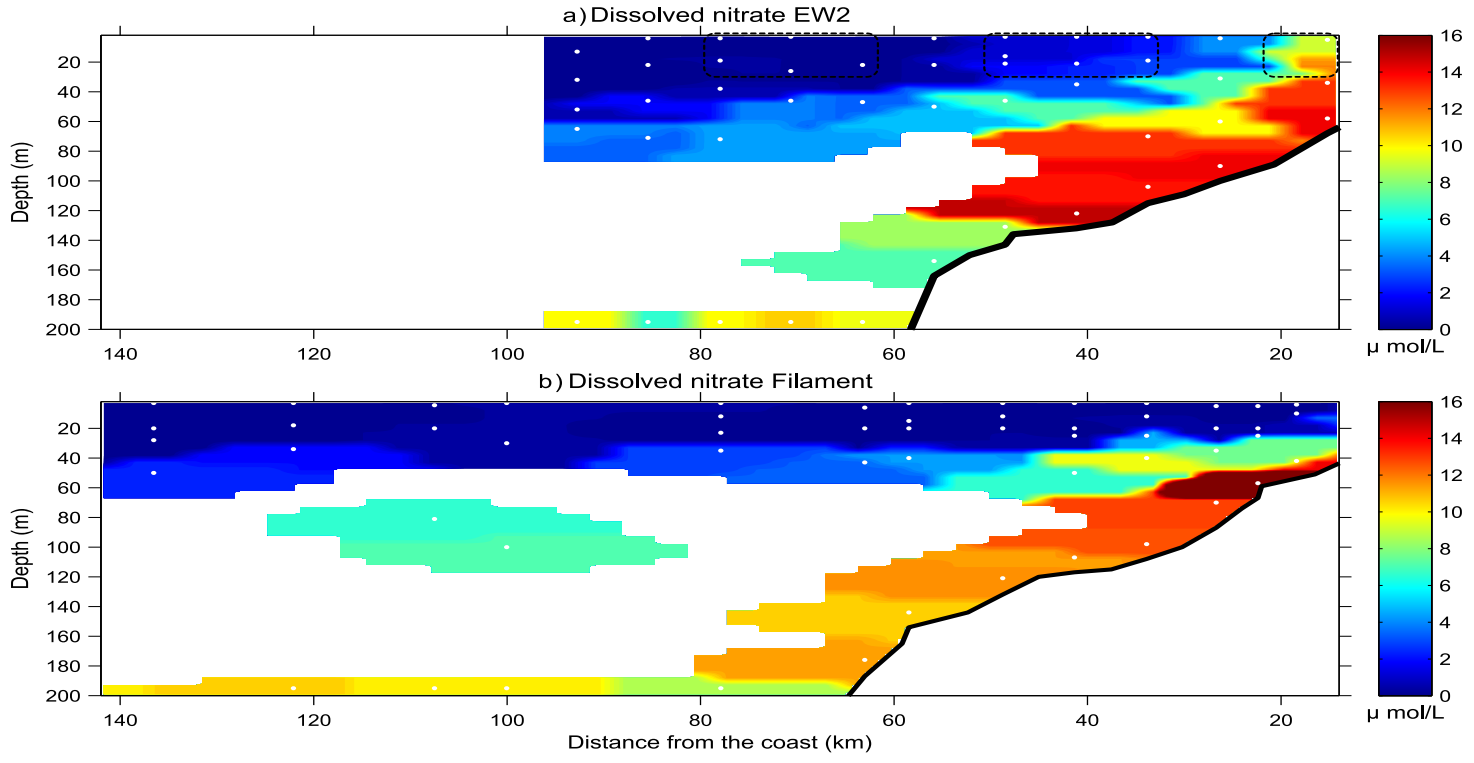

Figure 10: Distance from the coast $(\mathrm{km})$ versus depth profiles of Nitrate concentrations (from water samples in $\mu \mathrm{mol} / \mathrm{l}$ ) along a) EW2 and b) EW within the filament. White markers indicate the measurement positions; white areas are regions where data were too sparse to be robustly interpolated. Black dotted rectangles on panel a identify the successive upwelling fronts. The thick black lines represent the observed bathymetry. 
a) Phyto HPLC Pigments $(0-20 \mathrm{~m})$
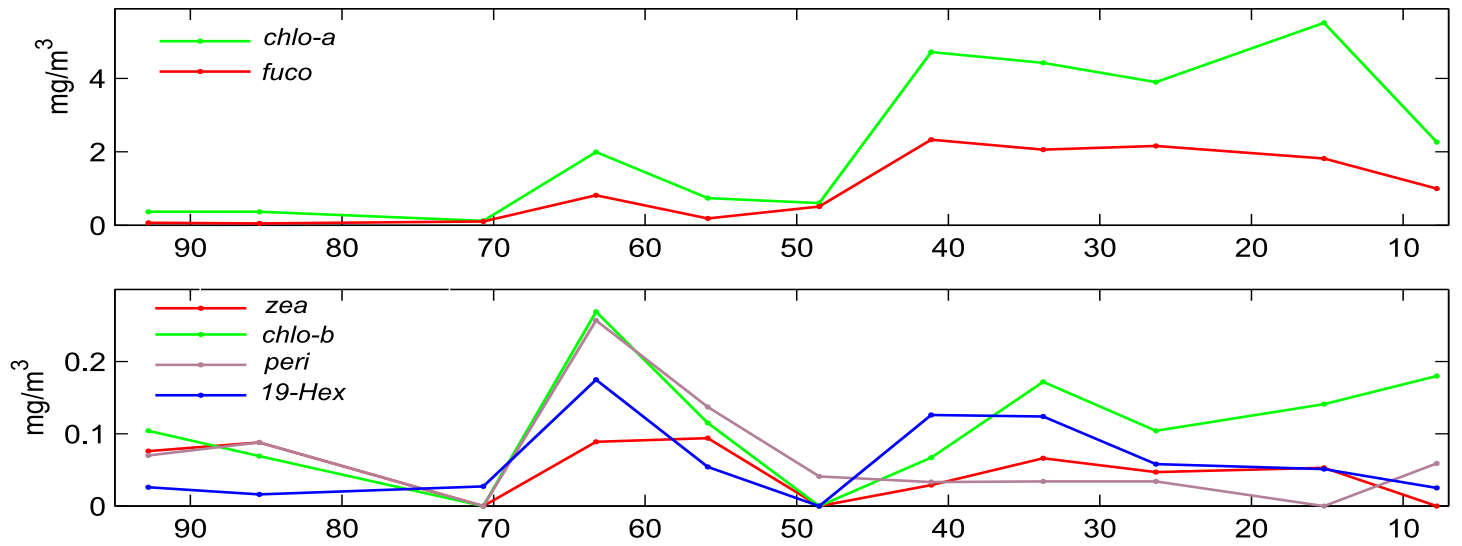

b) Size-fraction $(0-20 \mathrm{~m})$

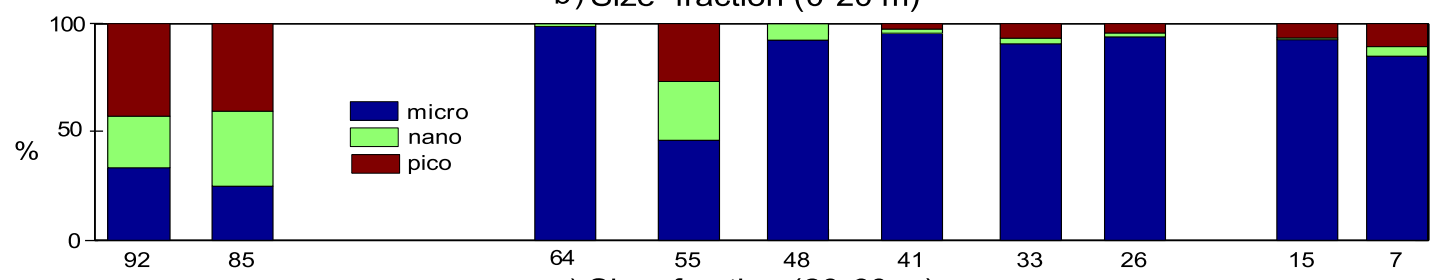

c) Size-fraction (20-60 m)

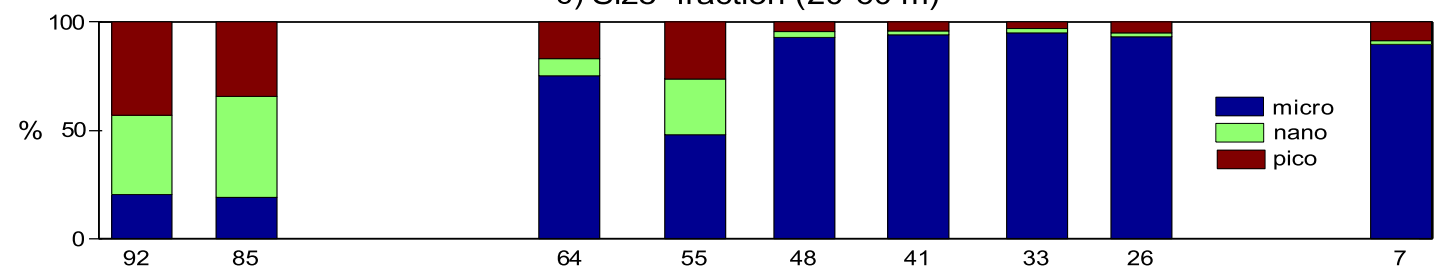

d) BioVolume Zoo(Living)

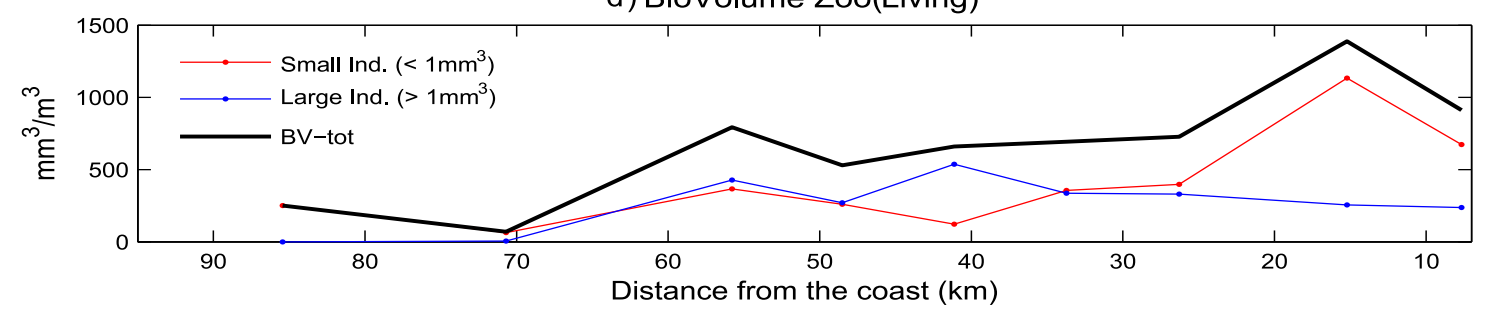

Figure 11: All data are for section EW2 at $40^{\circ}$ N. a) Selected phytoplankton pigments surface concentrations from HPLC (0-20 m, two upper panels); b,c) size-fractionated phytoplankton composition (percentage) at the surface (0-20 m) and sub-surface (20-60 m); d) Zooplankton biovolume (size-fractionated) using only the "living objects", as analysed by the Zooscan. 
a) Phyto HPLC Pigments $(0-20 \mathrm{~m})$
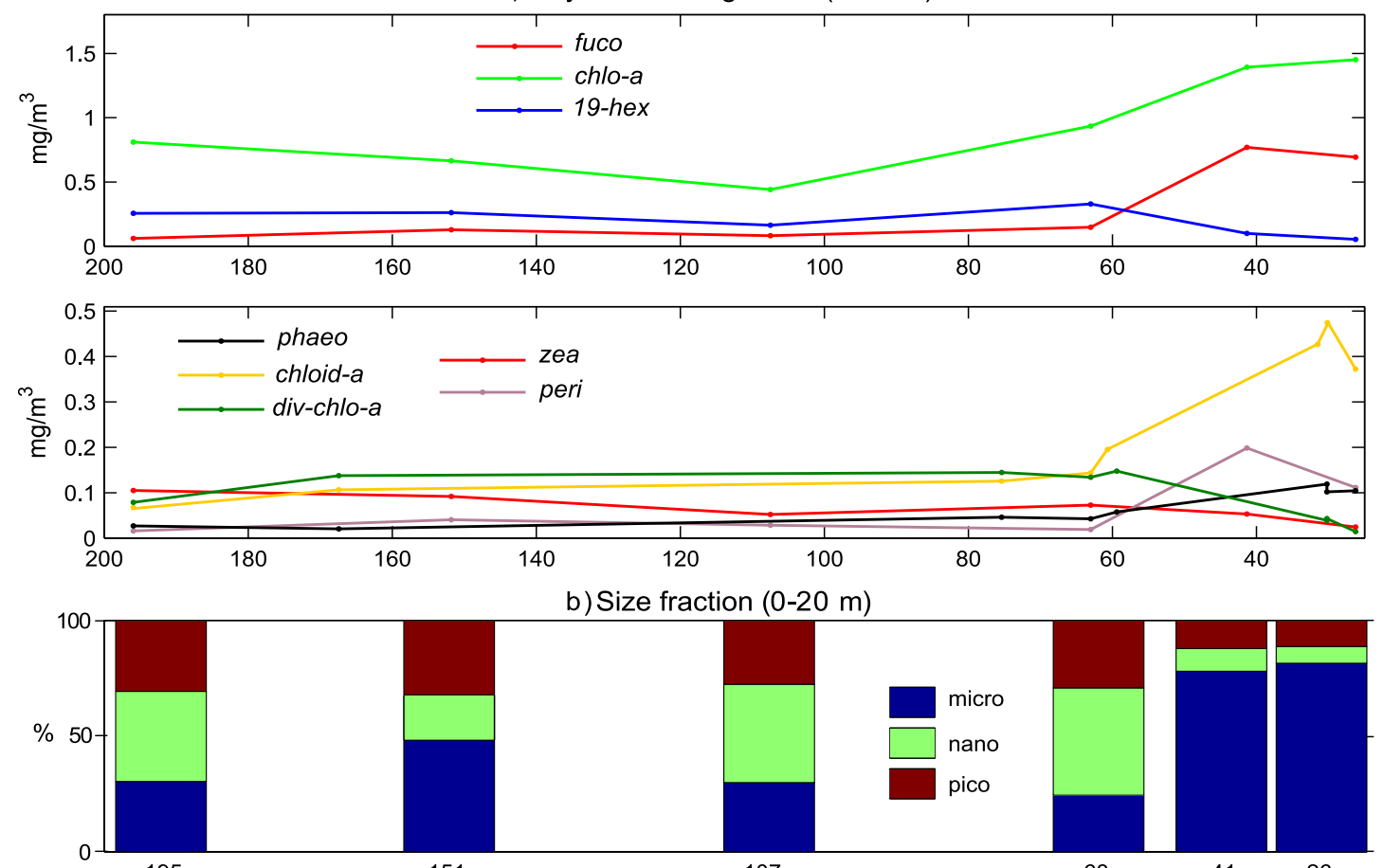

b) Size fraction $(0-20 \mathrm{~m})$

195

151

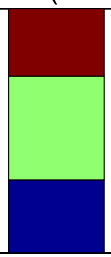

107

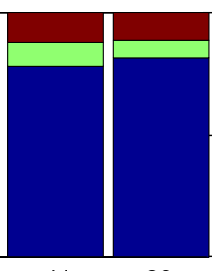

41

26

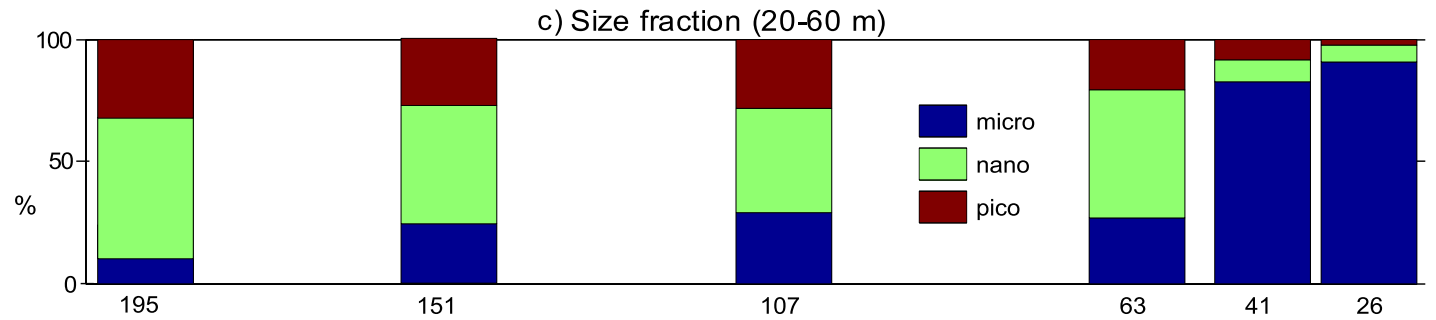

d) BioVolume Zoo(Living)

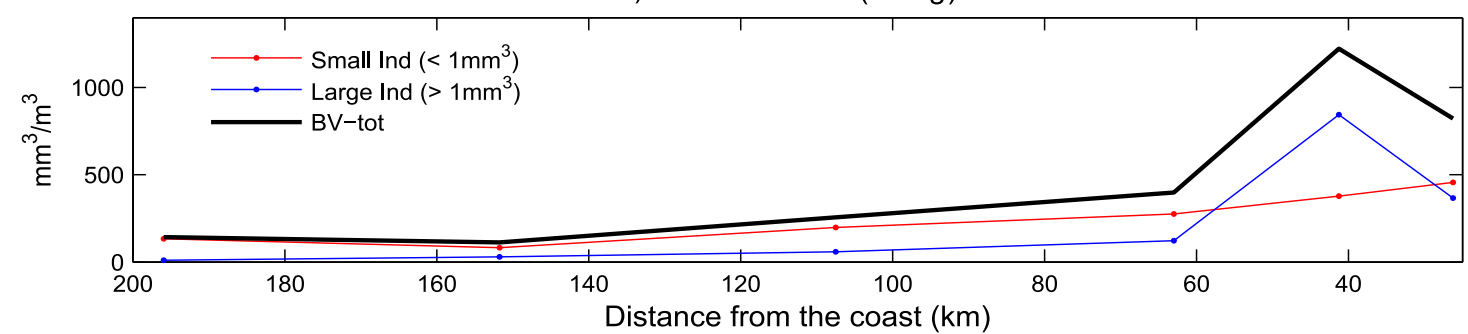

Figure 12: All data are for section EW within the filament. a) Selected phytoplankton pigments surface concentrations from HPLC (0-20 m, two upper panels); b,c) size-fractionated phytoplankton composition (percentage) at the surface (0-20 m) and sub-surface (20-60 m); d) Zooplankton biovolume (size-fractionated) using only the "living objects", as analysed by the Zooscan. 


\section{References}

Alvarez-Salgado, X., Aristegui, J., Barton, E., Hansell, D., 2007. Contribution of upwelling filaments to offshore carbon export in the subtropical Northeast Atlantic Ocean. Limnol. Oceanogr. 52, 1287-1292.

Alvarez-Salgado, X., Castro, C., Perez, F., Fraga, F., 1997. Nutrient mineralization patterns in shelf waters of the Western Iberian Upwelling. Cont. Shelf Res. 17, $1247-1270$.

Alvarez-Salgado, X., Doval, M., Borges, A., Joint, I., Frankignoulle, M., Woodward, E., Figueiras, F., 2001. Off-shelf fluxes of labile materials by an upwelling filament in the NW Iberian Upwelling System. Prog. Oceanogr. 51, 321-337.

Aminot, A., Kerouel, R., 2007. Dosage automatique des nutriments dans les eaux marines : méthodes en flux continu. Brest (France). Ed. IFREMER edition.

Arístegui, J., Barton, E., Alvarez-Salgado, X., Santos, A., Figueiras, F., Kifani, S., Hernández-León, S., Mason, E., Machu, E., Demarcq, H., 2009. Sub-regional ecosystem variability in the Canary Current upwelling. Prog. Oceanogr. 83, 33-48.

Barbosa, A., Galvao, H., Mendes, P., Alvarez-Salgado, X., Figueiras, F., Joint, I., 2001. Short-term variability of heterotrophic bacterioplankton during upwelling off the NW Iberian margin. Prog. Oceanogr. 51, 339-359.

Barton, E., Arístegui, J., Tett, P., Cantón, M., García-Braun, J., Hernández-León, S., Nykjaer, L., Almeida, C., Almunia, J., Ballesteros, S., Basterretxea, G., Escánez, J., García-Weill, L., Hernández-Guerra, A., López-Laatzen, F., Molina, R., Montero, M.F., Navarro-Pérez, E., Rodríguez, J., van Lenning, K., Vélez, H., Wild, 
K., 1998. The transition zone of the Canary Current upwelling region. Prog. Oceanogr. 41 (4), 455-504.

Batteen, M., Martinho, A., Miller, H., McClean, J., 2007. A Process-Oriented Study of the Coastal Canary and Iberian Current System. Ocean Model. 18, 1-18.

Batten, S., Fileman, E., Halvorsen, E., 2001. The contribution of microzooplankton to the diet of mesozooplankton in an upwelling filament off the north west coast of Spain. Prog. Oceanogr. 51, 385-398.

Borges, A., Frankignoulle, M., 2001. Short-term variations of the partial pressure of $\mathrm{CO}_{2}$ in surface waters of the Galician upwelling system. Prog. Oceanogr. 51, 283-302.

Brink, K., Cowles, T., 1991. The Coastal Transition Zone Program. J. Geophys. Res. 14, 637-647.

Capet, X., McWilliams, J., Molemaker, M., Shchepetkin, A., 2008. Mesoscale to Submesoscale Transition in the California Current System. Part I: Flow Structure, Eddy Flux, and Observational Tests. J. Phys. Oceanogr. 38, 29-43.

Castro, C., Perez, F., Alvarez-Salgado, X., Fraga, F., 2000. Coupling between the thermohaline, chemical and biological fields during two contrasting upwelling events off the NW Iberian Peninsula. Cont. Shelf Res. 20, 189-210.

Cermeno, P., Maranon, E., Perez, V., Serret, P., Fernandez, E., Castro, C., 2006. Phytoplankton size structure and primary production in a highly dynamic coastal ecosystem (Ría de Vigo, NW Spain): Seasonal and short-time scale variability. Estuar. Coast Shelf S. 67, 251-266. 
Cravo, A., Relvas, P., Cardeira, S., Rita, F., Madureira, M., Sanchez, R., 2010. An upwelling filament off southwest Iberia: effect on the chlorophyll a and nutrient export. Cont. Shelf Res. 30, 1601-1613.

Duró, A., Saiz, E., 2000. Distribution and trophic ecology of Chaetognaths in the western Mediterranean in relation to an inshoreoffshore gradient. J. Plankton Res. $22,339-361$.

Fileman, E., Burkill, P., 2001. The herbivorous impact of microzooplankton during two short-term Lagrangian experiments off the NW coast of Galicia in summer 1998. Prog. Oceanogr. 51, 361-383.

Fiuza, A., Macedo, M., Guerreiro, M., 1982. Climatological space and time variation of the Portuguese coastal upwelling. Acta Oecol. 5, 31-40.

Fréon, P., Barange, M., Arístegui, J., 2009. Eastern Boundary Upwelling Ecosystems: Integrative and Comparative Approaches. Prog. Oceanogr. 83, 1-14.

Garcia, H., Gordon, L., 1992. Oxygen Solubility in Seawater: Better Fitting Equations. Limnol. Oceanogr. 37, 1307-1312.

García-Munoz, M., Arístegui, J., Pelegrí, J., Antoranz, A., Ojeda, A., Torres, M., 2005. Exchange of carbon by an upwelling filament off Cape Ghir (NW Africa). J. Marine Syst. 54, 83-95.

Gasparini, S., 2007. Plankton Identifier: a software for automatic recognition of planktonic organisms. http://www.obsvlfr.fr/ gaspari/Plankton_Identifier/index.php.

Gorsky, G., Ohman, M., Picheral, M., Gasparini, S., Stemmann, L., Romagnan, J., Cawood, A., Pesant, S., García-Comas, C., Prejger, F., 2010. Digital zooplankton 
image analysis using the ZooScan integrated system. J. Plankton Res. 32 (3), 285-303.

Halvorsen, E., Hirst, A., Batten, S., Tande, K., Lampitt, R., 2001. Diet and community grazing by copepods in an upwelled filament off the NW coast of Spain. Prog. Oceanogr. 51, 399-421.

Haynes, R., Barton, E., Pilling, I., 1993. Development, Persistence, and Variability of Upwelling Filaments. J. Geophys. Res. 98, 22681-22692.

Heukelem, L.V., Thomas, C., 2001. Computer-assisted high performance liquid chromatography method development with applications to the isolation and analysis of phytoplankton pigments. J. Chromatogr. A 910, 31-49.

Joint, I., Groom, S., Wollast, R., Chou, L., Tilstone, G., Figueiras, F., Loijens, M., Smyth, T., 2002. The response of phytoplankton production to periodic upwelling and relaxation events at the Iberian shelf break: estimates by the ${ }^{14} \mathrm{C}$ method and by satellite remote sensing. J. Marine Syst. 32, 219-238.

Joint, I., Rees, A., Woodward, M., 2001. Primary production and nutrient assimilation in the Iberian Upwelling in August 1998. Prog. Oceanogr. 51 (2-4), 303-320.

Labasque, T., Chaumery, C., Aminot, A., Kergoat, G., 2004. Spectrophotometric Winkler determination of dissolved oxygen: re-examination of critical factors and reliability. Mar. Chem. 88 (1-2), 53-60.

Landry, M., Calbet, A., 2004. Microzooplankton production in the oceans. ICES Mar. Sc. 61, 501-507.

Landry, M., Ohman, M., Goericke, R., Stukel, M., Barbeau, K., Bundy, R., Kahru, M., 2012. Pelagic community responses to a deep-water front in the California 
Current Ecosystem: overview of the A-Front Study. J. Plankton Res. 34, 739748.

Lorenzo, L., Arbones, B., Tilstone, G., Figueiras, F., 2005. Across-shelf variability of phytoplankton composition, photosynthetic parameters and primary production in the NW Iberian upwelling system. J. Marine Syst. 54, 157-173.

Meunier, T., Rossi, V., Morel, Y., Carton, X., 2010. Influence of a bottom topography on an upwelling current: generation of long trapped filaments. Ocean Model. 35, $277-303$.

Motoda, S., 1959. Devices of simple plankton apparatus. Hokkaido University, Japan.. Faculty of Fisheries. edition.

Otero, P., Ruiz-Villarreal, M., Peliz, A., 2008. Variability of river plumes off Northwest Iberia in response to wind events. J. Marine Syst. 72, 238-255.

Pauly, D., Christensen, V., 1995. Primary production required to sustain global fisheries. Nature 374, 255-257.

Peliz, A., Dubert, J., Santos, A., Oliveira, P., Cann, B.L., 2005. Winter upper ocean circulation in the Western Iberian Basin - Fronts, Eddies and Poleward Flows: an overview. Deep-Sea Res. Pt I 52, 621-646.

Peliz, A., Rosa, T., Santos, A., Pissarra, J., 2002. Fronts, jets, and counter-flows in the Western Iberian upwelling system. J. Marine Syst. 35, 61-77.

Quaresma, L., Vitorino, J., Oliveira, A., da Silva, J., 2007. Evidence of sediment resuspension by non-linear internal waves on the western Portuguese mid-shelf. Mar. Geol. 246, 123-143. 
Queiroga, H., Silva, C., Sorbe, J., Morgado, F., 2005. Composition and distribution of zooplankton across an upwelling front on the northern Portuguese coast during summer. Hydrobiologia 545, 195-207.

Raimund, S., Quack, B., Bozec, Y., Vernet, M., Rossi, V., Morel, Y., Garçcon, V., Morin, P., 2011. Sources of short-lived bromocarbons in the Iberian upwelling system. Biogeosciences 8, 1551-1564.

Ras, J., Claustre, H., Uitz, J., 2008. Spatial variability of phytoplankton pigment distributions in the Subtropical South Pacific Ocean: comparison between in-situ and predicted data. Biogeosciences 5, 353-369.

Relvas, P., Barton, E., Dubert, J., Oliveira, P., Peliz, A., da Silva, J., Santos, A., 2007. Physical oceanography of the western Iberia ecosystem: Latest views and challenges. Prog. Oceanogr. 74, 149-173.

Resende, P., Azeiteiro, U., Goncalves, F., Pereira, M., 2007. Distribution and ecological preferences of diatoms and dinoflagellates in the west Iberian Coastal zone (North Portugal). Acta Oecol. 32, 224-235.

Ribeiro, A., Peliz, A., Santos, A., 2005. A study of the response of chlorophyll-a biomass to a winter upwelling event off Western Iberia using SeaWiFS and in-situ data. J. Marine Syst. 53, 87-107.

Roed, L., Shi, X., 1999. A numerical study of the dynamics and energetics of cool filaments, jets and eddies off the Iberian Peninsula. J. Geophys. Res. 104, 2981729841.

Rossi, V., 2010. Influence of mesoscale physical processes on planktonic ecosystems 
in the regional ocean: application to the Eastern Boundary Upwelling Systems. Ph.D. thesis. Université of Toulouse III Paul Sabatier / LEGOS, Toulouse, France.

Rossi, V., Morel, Y., Garçon, V., 2010. Effect of the wind on the shelf dynamics: formation of a secondary upwelling along the continental margin. Ocean Model. $31(3-4), 51-79$.

Sanchez, R., Relvas, P., Martinho, A., Miller, P., . Physical description of an upwelling filament west of Cape St. Vincent in late october 2004 .

Santos, A., Chícharo, A., dos Santos, A., Moita, T., Oliveira, P., Peliz, A., Ré, P., 2007. Physical-biological interactions in the life history of small pelagic fish in the Western Iberia Upwelling Ecosystem. Prog. Oceanogr. 74, 192-209.

Tilstone, G., Figueiras, F., Lorenzo, L., Arbones, B., 2003. Phytoplankton composition, photosynthesis and primary production during different hydrographic conditions at the Northwest Iberian upwelling system. Mar. Ecol-Prog. Ser. 252, 89-104.

Torres, R., Barton, E., 2007. Onset of the Iberian upwelling along the Galician coast. Cont. Shelf Res. 27, 1759-1778.

Varela, R., Roson, G., Herrera, J., Torres-Lopez, S., Fernandez-Romero, A., 2005. A general view of the hydrographic and dynamical patterns of the Rías Baixas adjacent sea area. J. Marine Syst. 54, 97-113. 